The Geneva Papers on Risk and Insurance, 23 (No. 89, October 1998), 540-607

\title{
Risk Securitization An Alternative of Risk Transfer of Insurance Companies
}

\author{
by Fred Wagner*
}

\section{The underlying problem}

The potential claims size of certain catastrophe risks does not only exceed the capacities of individual insurance companies (including the larger ones) ${ }^{1}$ but even reaches the capacity limits of the entire insurance market. This applies above all to some natural perils such as earthquakes, floods or storms (hurricanes) that can in certain, undoubtedly possible circumstances give rise to such large claim amounts that they exceed the entire global (re)insurance capacity ${ }^{2}$. At these capacity limits, the limits of insurability of such risks are also attained ${ }^{3}$.

* Professor, Lehrstuhl für Versicherungsbetriebslehre, Universität Leipzig.

${ }^{1}$ This became apparent at the latest in 1992 when the windstorm "Andrew" gave rise to insurance claims amounting to approx. USD $16 \mathrm{bn}$. As a result of this, the world's largest total insurance claim to date, a number of primary insurance companies and reinsurance companies had to go into liquidation. Cf., inter alia, anon.: Hannover Rück nutzt Kapitalmarkt für Rückversicherung (Hannover Re uses the Capital Market for Reinsurance), in: Frankfurter Allgemeine Zeitung, 03 December 1996, p. 23; Clow, R.: Coping with Catastrophe, in: Institutional Investor, December 1996, p. 137; Jahn, T.: Wetten auf das Wetter (Betting on the Weather), in: Capital, November 1996, p. 151; Palan, $D .:$ Nur noch heifle Luft - Mutige Anleger können jetzt darauf wetten, ob Naturkatastrophen hohe Schäden verursachen oder nicht (Still only Hot Air - Adventurous Investors can now bet on whether Natural Catastrophes will give rise to High Claims or not), in: Wirtschaftswoche, 03 October 1996, p. 184 and Swiss Re (publisher): Natural Catastrophes and Major Losses 1996: High Man-made Losses, Absence of extremely costly Natural Catastrophes, in: sigma, 1997, No. 3, p. 37 (Table 6: "The 40 most expensive insured losses 1970 - 1996" with amounts converted to 1996 prices).

${ }^{2}$ Cf. Meyer, B.: Cover need not be Catastrophic, in: Reinsurance, July 1996, p. 37.

${ }_{3}$ Cf. Gonseth, M.: Assekuranz transferiert Risiken immer stärker auf die Finanzmärkte (Insurance Increasingly Transfers Risks to the Capital Markets), in: Handelsblatt, 24 September 1996, p. B11 and, more exhaustively, Gollier, C.: About the Insurability of Catastrophic Risks, in: The Geneva Papers on Risk and Insurance, (22) 1997, p. 177 et seq. 
It is particularly in the area of natural perils that an increase in the number and size of catastrophe claims has been observed around the world in recent times 4,5 . Whether and to what extent this is coincidence or a trend signalling further future increases in the number and/or size of natural catastrophes - e.g. due to climatic changes - remains to be seen. An important role is certainly played by the increasing geographic concentration ${ }^{6}$ of people and assets, sometimes in areas particularly subject to catastrophe risks, ${ }^{7}$ leading to increasing claim sizes in the event of earthquakes, floods, storms etc. ${ }^{8}$

In view of these capacity limits and related limits of insurability, the idea arises of making available additional capacity for catastrophe risks outside the insurance market. The international capital market would be suitable for this ${ }^{9}$ as, in the economies of developed countries, its degree of capitalisation is many times greater than that of the insurance market ${ }^{10}$. Thus, for example, the total published shareholders' equity of all

${ }^{4}$ Cf. Brooks, K. H.: New ways to cut US Catastrophe Exposures, in: ReActions, (16) 1996, September, p. 125; Kielholz, W.; Durrer, A.: Insurance Derivatives and Securitization: New Hedging Perspectives for the US Cat Insurance Market, in: The Geneva Papers on Risk and Insurance, (22) 1997, No. 82, p. 3; Meyer, B.: loc. cit., p. 37 and Swiss Re (publisher): Natural Catastrophes and Major Losses 1996: High Man-made Losses, Absence of extremely costly Natural Catastrophes, loc. cit., p. 8 et seq. (Development since 1970: Trend to expensive major losses continues). This is not basically contradicted by the reduced burden of natural catastrophes in the past two years 1996 and 1997. Rather it can be interpreted as a manifestation of the strong volatility of the overall development. Cf. ibid. p. 13 et seq.

${ }^{5}$ Even if the frequency of occurrence of earthquakes, floods, storms etc., as such, has not altered significantly in the past, the number of natural losses of catastrophic proportions (= natural catastrophes) has increased. The reason for this is the increase in the claim amounts in respect of the individual natural occurrences. (From the scientific point of view there is not, as yet, any conclusive evidence of changed, in particular of increased, frequency of such natural occurrences, cf. ibid. p. 8. Notwithstanding this, contradictory statistical statements are to be found in the literature. Thus assertions are made of a reducing frequency since the end of the 70's as well as of a markedly increasing frequency since the 60's. Cf. Smith, R. E.; Cancelo, E. A.; Di Dio, A. M.: Reinventing Reinsurance using the Capital Markets, in: The Geneva Papers on Risk and Insurance, (22) 1997, p. 26 and Figge, F.: Spekulieren mit der Katastrophe (Speculating with Catastrophe), in: Blick durch die Wirtschaft, 23 October 1996, p. 10.

$6 \mathrm{Cf}$. anon: Münchener Rück zur weltweiten Verstädterung (Munich Re on World-wide Urbanisation), in: Die Versicherungspraxis, (87) 1997, p. 115; anon.: Naturkatastrophen mit Anlegergeldern versichern (Insure Natural Catastrophes with Investment Funds), in: Handelsblatt, 23 July 1996, p. 13. and Meyer, B.: loc. cit., p. 37.

${ }^{7}$ Cf. Kielholz, W.; Durrer, A.: loc. cit., p. 3 and Smith, R. E.; Cancelo, E. A.; Di Dio, A. M.: loc. cit., p. 26.

${ }^{8} \mathrm{Cf}$. anon. (H.C.): Extreme Risiken durch weltweite Verstädterung (Extreme Risks resulting from World-wide Urbanisation), in: Versicherungswirtschaft, (52) 1997, p. 851, with explanatory data in relation to the estimated potential size of economic and/or insured losses from such natural catastrophes in Florida, Los Angeles, New York, San Francisco, Tokyo and the 'heavily populated European centres'. Cf. also Magenheim-Hörmann, T.: Die Angst der Assekuranz vor der Metropole (Insurers' Worries in Connection with the Metropolis), in: Frankfurter Rundschau, 16 May 1997, p. 11.

9 Cf. anon.: Risikotransfer über Finanzmärkte (Risk Transfer via Capital Markets) in: Die Versicherungspraxis, (86) 1996, p. 166; Kielholz, W.; Durrer, A.: loc. cit., p. 3; Müller, E.: Securitization - Quo Vadis?, in: Zeitschrift für Versicherungswesen, (48) 1997, p. 597 and Shimpi, P.: The Context for Trading Insurance Risks, in: The Geneva Papers on Risk and Insurance, (22) 1997, p. 17 et seq. p. 17

${ }^{10} \mathrm{Cf}$. also Vukelic, M.: Access to a Wealth of Capital Ideas, in: Reinsurance, September 1996, 
property and casualty insurance companies in the USA is only approx. USD 200 billion $^{11}$, whereas the assets traded in the capital market there account for some USD 19,000 billion ${ }^{12,13}$. It is in the USA also that the first steps were undertaken towards the utilisation of the capital market for covering natural catastrophe risks ${ }^{14}$.

\section{Overview of various "alternative means" of risk transfer}

\subsection{Transactions relating to insurance index derivatives}

It has been possible to carry out transactions relating to insurance index derivatives since 11th December 1992 at the Chicago Board of Trade (CBoT) ${ }^{15}$. These are not concerned with contracts for performance; as is normally the case with transactions

11 Of which approx. USD $20 \mathrm{bn}$. fall on the reinsurance companies. Simulations show that one single earthquake in California or a hurricane over Florida could cause insured probable maximum losses of up to USD 100 bn. (The possible maximum loss in San Francisco/California is estimated in the literature as up to USD $220 \mathrm{bn}$. As regards an earthquake in Greater 'Tokyo, an amount as high as USD 3,300 bn. has been suggested. Cf. Meyer, B.: loc. cit., p. 38). Additionally, the free reserves of the insurance company must allow for all other insured risks, that is to say for the excess claims potential over and above that covered by the premiums and the security loadings in respect thereof. Cf. Durrer, A.: Alternativer Risikotransfer über Finanzmärkte (Alternative Risk Transfer via Capital Markets), in: Versicherungswirtschaft, (51) 1996, p. 1198 and Kielholz, W.; Durrer, A.: loc. cit., p. 3. Smith et al. explain further that the part of the total free reserves which is allocated to covering catastrophe risks is no longer available to support the other, less exposed and potentially more profitable risks. Cf. Smith, R. E.; Cancelo, E. A.; Di Dio, A. M.: loc. cit., p. 28.

${ }^{12}$ Cf. Clow, R.: Coping with Catastrophe, in: Institutional Investor, December 1996, p. 137 et seq. Geman, H.: Insurance Risk Securitization and Cat Insurance Derivatives, unpublished lecture manuscript, Paris, July 1996, p. 2 and Durrer, A.: loc. cit., p. 1198. Durrer states further that the daily fluctuations in value of traded securities in the USA amounting on average to USD 133 bn. exceed the insured probable maximum loss of an earthquake catastrophe. In this respect see also Kielholz, W.; Durrer, A.: loc. cit., p. 3; Punter, A.: An Engagement is Announced, in: Reinsurance, April 1996, p. 9 and Smith, R. E.; Cancelo, E. A.; Di Dio, A. M.: loc. cit., p. 27.

13 The free reserves of the insurance market world-wide are estimated at about USD 500 bn:; the value of the securities traded on the capital markets is estimated at some USD 40,000 bn. Cf. Gonseth, $M .:$ loc. cit., p. B11, according to whom "the daily fluctuations in value (i.e. of the assets in the capital markets - author's note) can easily be as much as USD 150 bn. and so exceed the recorded losses ever caused by one earthquake or storm". 166.

${ }^{14}$ Cf. anon.: Risikotransfer über Finanzmärkte (Risk Transfer via Capital Markets), loc. cit., p.

$15 \mathrm{Cf}$. and see more exhaustively, Albrecht, P.; König, A.; Schradin, H. R.: Katastrophenversicherungs-Terminkontrakte: Eine Finanzinnovation und ihre Bedeutung für die (Rück) Versicherung von Katastrophenrisiken (Catastrophe Insurance Futures: A Financial Innovation and its Significance for the (Re)Insurance of Catastrophe Risks), in: Zeitschrift für die gesamte Versicherungswissenschaft, (83) 1994, S. 639 et seq.; Cox, S. H.; Schwebach, R. G.: Insurance Futures and Hedging Insurance Price Risk, in: Journal of Risk and Insurance, (59) 1992, p. 628 et seq; D'Arcy, S. P.; France, V. G.: Catastrophe Futures: A Better Hedge for Insurers, in: Journal of Risk and Insurance, (59) 1992, p. 575 et seq.; the same: Catastrophe Insurance Futures, in: CPCU Journal, (46) 1993, p. 202 et seq.; Durrer, A.: loc. cit., p. 1198; Hasekamp, U.: Insurance Futures - eine Finanzinnovation als Hedging-Instrument gegen Katastrophenrisiken? (Insurance Futures - a Financial Innovation as a Hedging Instrument against Catastrophe Risks?), in: Versicherungswirtschaft, (49) 1994, p. 361 et seq.; Himick, M.: CBOT PCS Cat Options, in: Reinsurance, September 1996, p. 19 et seq. (discusses further the grounds for the transactions and the market developments); Mansion, Y.; Cossu, P.: Assurance et finance - Vers un pont à double voie?, in: Risques, No. 28, 1996, p. 80 et seq.; Weber, M.: Cat Option Critique, in: Reinsurance, September 1996, p. 21 et seq. and Kielholz, W.; Durrer, A.: loc. cit., p. 6 et seq. 
relating to index derivatives, closing out can only be carried out by an appropriate contratransaction. The basis value for an insurance index derivative is the claims ratio of a specified reference portfolio ("pool") of insured risks. The pool is a fictional portfolio of risks relating to natural catastrophe covers that are actually insured by specified insurance companies, the "pool insurers".

The traded derivatives which are discussed here are in principle designed in such a way that their final monetary value increases according to the extent of the claims arising from the pool risks, i.e. with rising claims ratios. The daily prices, and thus the price at the commencement of a contract, arise through market mechanisms, in other words by agreement between the parties to the contract. The profit or loss positions of the parties to the insurance index derivatives transaction arise from the difference between the price at the commencement of the contract and the "final settlement price".

Following on from the main types of insurance index derivatives, a distinction must be drawn between insurance index futures and insurance index options. In the case of the insurance index futures, the final settlement price is the final claims ratio of the pool, multiplied by USD 25,000. The parties to the contract must settle the difference at the due date between the price at the commencement of the contract and the final settlement price. Herein lies the central difference to options, of which only the purchase options (call options) on insurance index futures will be discussed here. The buyer of such call options can - within a specified period - purchase insurance index futures at an exercise price agreed when the option transaction is entered into; the buyer acquires the right but is under no obligation to do so. A more recent type of options that is also a variation on insurance index derivatives enjoying greater success in the market is the "call options spread"16. This involves purchases of call options on insurance index futures at specified exercise prices and simultaneously selling call options at higher exercise prices.

With the help of all the above types of insurance index derivatives, insurance companies are able - if they are acting as buyers - to build up similar risk positions to those provided by passive reinsurance. If there is a high degree of positive correlation between the claims ratio of the pool and that of a company's own portfolio of insured risks, the effects of purchasing insurance index futures will be similar to those of passive proportional reinsurance. This is because the insurer always tends to make a profit from the futures transaction when suffering a loss on his own insurance business; conversely, he incurs a loss on the futures transaction if he makes a profit from his own insurance business. The degree of the profits and losses run more or less in parallel, according to the degree of correlation between the claims ratios of the pool and the company's own portfolio of insured risks. By purchasing call options on insurance index futures, the insurer limits his potential loss on this transaction to the option price. On the other hand, however, he will forfeit the overall probability of profit arising from the possibility of a high claims ratio of the pool. If the claims ratio of the pool is high, then the insurance index futures will also be "very valuable", as will the call options on the insurance index futures. If the claims ratio of the company's own portfolio of insured risks is correspondingly high, then the profit on the call options will be countered by a loss on the insurance business. The purchase of call options is therefore similar in its effects to passive

${ }^{16}$ See in this connection also Smith, R. E.; Cancelo, E. A.; Di Dio, A. M.: loc. cit., p. 32 et seq. 
annual excess of loss reinsurance with wide layers of cover ${ }^{17}$. When purchasing call option spreads, the probability of profit on each contract is limited to the difference between both exercise prices. The position thereby reached is similar in its effects to passive annual excess of loss reinsurance with a narrow layer of cover.

In so far as the sellers are not insurance companies but other investors, a transfer of risk from the insurance market to the capital market takes place with the help of insurance index derivatives.

\subsection{Catastrophe Risk Exchange (CATEX)}

A further alternative for transfer of risk from insurance companies has been available since October 1996, again in the USA and more precisely in New York where a special exchange for insured catastrophe risks was founded, the "Catastrophe Risk Exchange (CATEX)"18, which enables licensed risk carriers to exchange specific catastrophe risks between each other ${ }^{19}$. Licensed risk carriers include primary insurance and reinsurance companies and insurance brokers, as well as captives of large concerns outside the insurance industry. The exchange transactions are processed via an electronic mail-box in which the risk carriers post the precise descriptions of the catastrophe risks they consider for exchange. At the opening of daily trading, the CATEX system calculates a set of hypothetical exchange rates which are based on historic claims distributions and the latest dealing rates. These can be regarded as relative prices which adjust to the actual market situation automatically and within split seconds, so that supply and demand are brought into balance as nearly as is possible.

The CATEX system operates without the involvement of the capital markets. No transfer of risk from the insurance market takes place. Without doubt, however, the possibilities for risk diversification within the insurance market are improved; in this way the capital available to the insurer to cover risks can be used more efficiently. Through the inclusion within the exchange of captives which, in general, do not participate in the traditional insurance market for catastrophe risks, the circle of risk carriers is enlarged. The overall desired result is again an increase in the available total market capacity ${ }^{20}$.

\subsection{Risk Securitization: A basic model}

"Risk securitization" can be regarded as a special form of reinsurance. Originally developed in the USA, it involves the transfer of insured risks, usually catastrophe risks, from insurance companies to the capital market and the investors operating therein. The concept is based on the following method of operation: ${ }^{21}$

${ }^{17}$ The spread of each "layer of cover" of the seller of insurance index futures, or call options based thereon, is always limited to USD 50,000. This amount is the upper limit of the settlement price laid down by the CBoT.

${ }^{18} \mathrm{Cf}$. in this, and in the following, connection Banham, $R$ : Breaking Barriers, in: ReActions, (17) 1997, March, p. 64; Clow, R.: loc. cit., p. 138 et seq.; Durrer, A.: loc. cit., p. 1198; Kielholz, W.; Durrer, A.: loc. cit., p. 3; Mansion, Y.; Cossu, P.: loc. cit., p. 82 and Smith, R. E.; Cancelo, E. A.; Di Dio, A. M.: loc. cit., p. 34.

${ }^{19}$ For example earthquake risks in California for hurricane risks in Florida. Transactions cover, in total, a dozen US-American regional catastrophe risks.

${ }^{20}$ Reference to a critical analysis of the CATEX system appears in Brooks, $K$. H.: loc. cit., p. 126.

${ }^{21}$ Note: The basic model (see illustration) assumes the interposition of a Trustee who undertakes certain functions although this is not obligatory as discussed in Chapter 3.3. In relation to the basic model, cf. also similar model illustrations in Vukelic, M.: loc. cit., p. 18. 
Figure 1

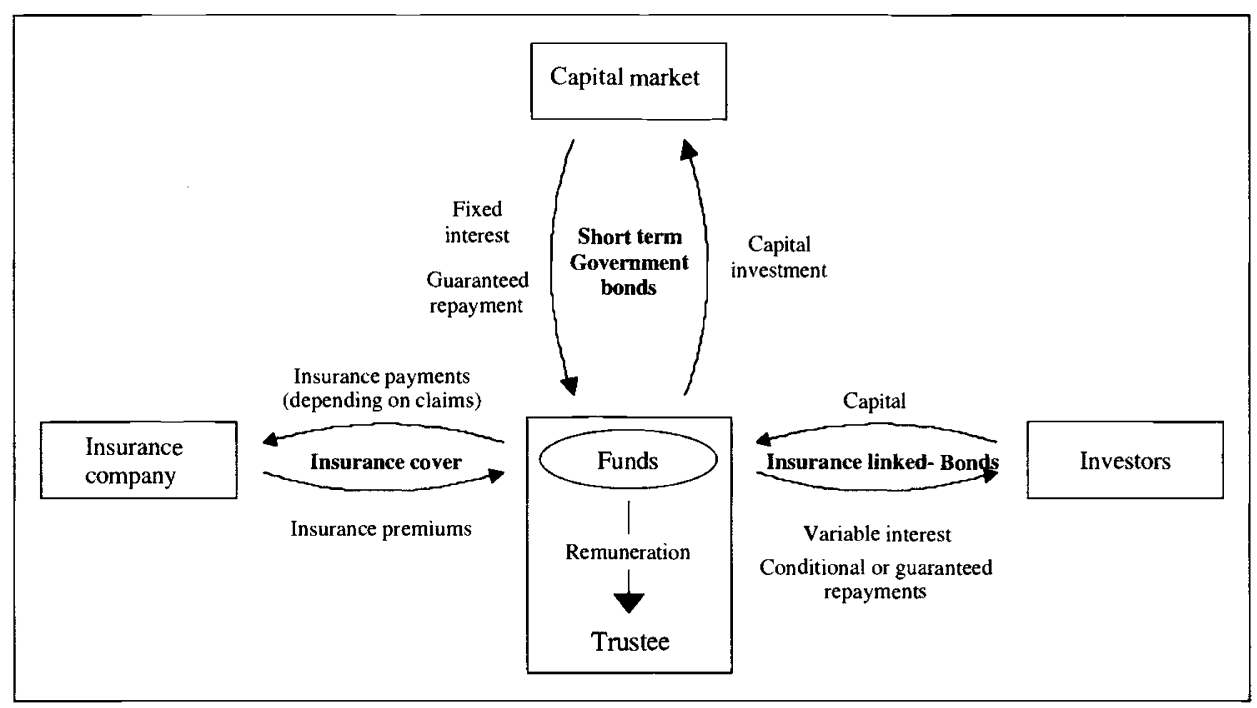

In return for specified capital payments, the investors purchase "insurance-linked bonds" that are issued by a Trustee on acceptable terms. The insurance-linked bond is a security with a conditional or unconditional entitlement to repayment and usually an entitlement to a variable rate of interest. The rate of interest and, in some cases, the repayment of capital are dependant on certain insured catastrophe risks; these risks are documented in the security in question (= "risk securitization"). Provision of interest is met from two sources: Firstly, from the insurance premiums paid by the insurance company (or companies) to the Trustee in order to transfer its (their) catastrophe risks. Secondly, payments derived from investments in short term Government bonds made by the Trustee and financed mainly by investors' capital as well as by the insurance premiums. If no transferred ("reinsured") catastrophe claims arise during the term of the insurancelinked bond, the investors receive full repayment of their capital - less the fees of the Trustee - as well as the maximum agreed rate of interest. However, if there are transferred catastrophe claims, the insurance company or companies are initially reimbursed from the general fund comprising insurance premiums, investors' capital and those investment returns already received; the transfer of risk is thus crystallised. (In the event of an unconditional entitlement to repayment, the initial capital of the investors is not drawn upon to finance the incurred claims). Typically, the balance is then available for distribution to the investors (again after deduction of the Trustee's fees). The "risk securitization" concept represents a further possible method of transferring insured risks over and above the capacity of the (re)insurance market through additional use of the capital market ${ }^{22}$.

22 For simplicity, the term "securitization" is used in the following in place of "risk securitization". 


\section{Variations on Risk Securitization arising from different effects of individual model parameters}

\subsection{Types of insurers transferring risks}

Both primary insurance and reinsurance companies can use the securitization concept to transfer risk, either as a substitute for, or in addition to, the use of traditional reinsurance ${ }^{23,24}$. Of the primary insurers it is above all the large companies with corresponding catastrophe risks in their insurance portfolios that are possible users. For the purposes of placing the "insurance-linked bonds", they should also benefit from their greater public profile, specifically with investors in the capital market. In fact for private investors the large primary insurance companies are for the most part better known than the reinsurance companies. One disadvantage for the prospects of success for insurance companies wishing to transfer risk by means of securitization can be the lack of understanding by most types of investors in the capital market of the insurance business, including insurance techniques and the transformation of insurance risks into capital market risks ${ }^{25}$. Depending on the nature of the "insurance link" of the bonds to be placed, a fundamental understanding of the insurance business and techniques is of considerable importance for the ability of investors to assess the attractiveness of the investment conditions - particularly if taking into account the risks involved ${ }^{26}$. In principle the same applies when a reinsurance company wants to transfer risks. However, in this instance, it is possible that there is greater investor confidence in the "insurance-linked bond" to be placed for the simple reason that the underlying insurance transaction risks have already been underwritten by a specialist with best knowledge of them - the reinsurance company itself - and have obviousley been found acceptable. Here it is sometimes overlooked that the nature and extent of securitized bond risks can differ as to form and extent from those of the original insurance risks ${ }^{27}$. Confidence should in any case be strengthened by the fact that the insurance company concerned wishes only to transfer a part and not the whole of a particular catastrophe risk to the capital market and will retain the remainder for its own account ${ }^{28}$. Investors are naturally more willing to make an investment involving risk if the

${ }^{23}$ In theory, the original risk carriers outside the insurance industry could be considered as users, more particularly large concerns from all other branches of industry. With them in view securitization can be considered as an extension or alternative to effecting traditional primary insurance. This aspect is however not discussed in this paper. Cf. also Punter, A.: An Engagement is Announced, loc. cit., p. 8 who regards "even insureds" as potential issuers of insurance-linked bonds. Further see Dowding, T: Safe as Houses?, in: The Post Magazine, Vol 158, 6 March 1997, p. 6.

${ }^{24}$ From the point of view of the insurer, securitization can also be undertaken as an alternative to insurance index futures transactions. A comparison of these two vehicles for risk transfer to the capital market - with their particular advantages and disadvantages - is also not discussed in this paper. Finally, there is no comparative assessment with the use of the "Catastrophe Risk Exchange" (CATEX) for risk transfer. See in this connection Kielholz, W.; Durrer, A.: loc. cit., p. 10.

${ }^{25}$ Cf. Ballantine, R.: Bonding Experience, in: ReActions, (16) 1996, September, p. 91 and Clow, R.: loc. cit., p. 138.

${ }^{26}$ That the investors are not adequately qualified to estimate the underlying insurance risks is emphasised in anon. (H.C.): Extreme Risiken durch weltweite Verstädterung (Extreme Risks resulting from World-wide Urbanisation), loc. cit., p. 852.

${ }^{27}$ See further Chapter 3.4.

${ }^{28}$ As to a reinsurer being credited with greater trustworthiness as a catastrophe risk specialist if he risks his own capital by an appropriate self-retention, cf. anon.: Vorstoß im Bereich des alternativen Risikotransfers (Advances in the Field of Alternative Risk Transfer), in: Handelsblatt, 04./05. October 1996, p. 29. 
party benefiting from the receipt of the risk coverage capital continues to retain a substantial participation in the same risk ${ }^{29}$.

\subsection{Types and quantities of insured risks as subject of risk transfer}

It is already clear that the quantity of the transferred risk or the appropriate part thereof represent an important determinant in securitization. As already stated, in terms of type of risk, the risk transfer is primarily concerned with natural catastrophes e.g. earthquakes, floods and storms as well as the losses that can arise therefrom. War and civil unrest are also prime subjects for inclusion. These are all examples of accumulation risks that cannot - or only to a limited extent - be insured by traditional means due to insufficient capacity for the high loss potential. Theoretically speaking, all risks can ultimately be transferred to the capital market by securitization ${ }^{30}$, the various types of risks can be transferred either individually or in combination with each other - and thus already diversified, in so far as there are no major correlations ${ }^{31}$.

All the risks mentioned above, as well as others suitable for transfer, can stem from insurance covers within individual classes of insurance or from defined combinations of classes. This can be illustrated by reference to the example of storms: Risks of the first case are those arising solely from storm insurance that are to be transferred to the capital market by means of securitization; in second place are the associated risks from other classes of insurance providing storm covers, e.g. comprehensive covers for household buildings, household contents and / or motor vehicles. By appropriate definition, the insurance company can make a precise selection of the types of cover for which reinsurance is to be sought in the capital market on the basis of the specified risk or combination of risks covered. Apart from the classes of insurance to be included (that can themselves be further divided into sub-classes), securitization can be based on business regions or risk locations $s^{32}$ and / or customer groups as risk-related structural parameters ${ }^{33}$.

So far only risks arising from insurance portfolios or partial portfolios have been considered. In principle individual risks could also be transferred to the capital market by

${ }^{29}$ As an alternative, the insurance company itself, or a company within the same group or a cooperating (insurance) company - preferably having experience in the type of insurance risk involved - might purchase a larger block of the insurance-linked bonds in question. Cf. Clow, R.: loc. cit., p. 142.

${ }^{30}$ For the discussion about particularly suitable and less suitable risks see the brief and concise statements in Punter, A.: Something out of the Ordinary, in: Reinsurance, December 1997, p. 18. In this essay the low severity, high frequency risks are favoured, which are covered e.g. in the personal and motor insurance - just in contrast of what has been discussed in theory and practice, where the high severity, low frequency risks are considered to be more suitable. According to the author the risks with a long-tail claims adjustment, such as in the liability insurance, are most unlikely to become securitized.

${ }^{31}$ Cf. Quick, C.: Securitization 'First' on Non-Disaster Risks, in: Insurance Day, 08 April 1997, as follows: "Multiline insurance classes are attractive since they provide a portfolio of diversified risks within a single instrument", also Shimpi, P.: loc. cit., p. 24 ("diversification by peril").

${ }^{32} \mathrm{Cf}$. in this connection also Shimpi, P.: loc. cit., p. 24 ("diversification by geography").

${ }^{33}$ The effect of diversification can even be improved if the investors do not only tie up with the risks of a single insurer but at once with the scattered risks of several or many insurers. This is for instance describable by a fund model. Behind that there is the idea of bringing together the risks of various insurance companies into a "fund for risks", in which the investors are involved via 
means of securitization; however, with a few exceptions, there would appear to be little demand for this. Even when individual insurance companies have insufficient capacity for particular individual risks, an insurance solution is nevertheless usually possible through a suitable method of risk sharing (coinsurance, reinsurance, insurance pools). Exceptions relate particularly to those individual risks that even the existing pool agreements can only cover to a limited extent - for example, atomic risks ${ }^{34,35}$.

Many insurance covers are not solely limited to the insured perils but are additionally - or alternatively - restricted to the insured items and / or types of loss ${ }^{36}$. These restrictive characteristics should also be taken into account in securitization, if a high Fdegree of "risk hedging efficiency" is to be attained - in the sense of balancing so far as possible the opposing results from the risks assumed by the active insurance transactions on the one hand and the risk reduction under the related capital market transactions on the other hand. Conversely the planned building up of incomplete hedge positions is possible, if not all insured perils, items and / or types of loss - with their potential claims values - are transferred to the capital market. In particular it may be desired to transfer only those particularly "dangerous" potential losses, e.g. involving very high amounts and low occurrence probabilities that may apply only to certain perils, items or types of loss. In all actual or potential limitations of insurance covers there are also the determinants for risk transfer by securitization.

\subsection{Types of Trustees as intermediaries between insurers and investors}

The basic model that has been described above envisages the interposition of a "Trustee" to act as an intermediary between the insurance company and the investors. In addition to the provision of the Trust function and his ability to assist investors by countering the insurer's information advantage, there are the following advantages: the Trustee can have a business relationship with the insurance company having expertise in insurance matters and can therefore negotiate fair conditions and, above all, equitable premiums for the transfer of risk. In addition, the Trustee can assist in drawing up and placing the insurance-linked bonds by having the interested clients and providing them, inter alia by means of the necessary infrastructure.

\footnotetext{
${ }^{34}$ As to the possibilities and limits of 'pool solutions' for atomic energy risks and, in particular the German Atomic Energy Pool, see more extensively, Rehmann, J.: Vierzig Jahre Nuklearversicherung: Ist das Poolsystem noch Zeitmässig? (Forty Years of Nuclear Insurance. Is the Pool System still Appropriate to the Times?), in: Neue Wege des Versicherungsmanagements (New ways in insurance management), Festschrift for the 60th birthday of Günter Schmidt, ed. by J.-M. Graf von der Schulenburg, Karlsruhe 1997, p. 305 et seq.

${ }^{35}$ Large environmental risks and product liability risks are also examples where the sums insured provided by insurers are only available up to definite upper limits. A project is already being undertaken in New York with a view to securitizing and transferring to the capital market the product liability risks of pharmaceutical and medical apparatus manufacturers; cf. Ballantine, R.: Capitalising on Risk, in: ReActions, (16) 1996, September, p. 90. Political risks, including the risks of terrorist attacks and acts of sabotage in large cities with high concentrations of populations and assets loom ever larger in the foregoing connection. Cf. also Magenheim-Hörmann, T.: loc. cit., p. 11 and the following articles (all anon.): Hannover Rück nutzt Kapitalmarkt für Rückversicherung (Hannover Re uses the Capital Market for Reinsurance), loc. cit., p. 23; Münchener Rück zur weltweiten Verstädterung (Munich Re on World-wide Urbanisation), loc. cit., p. 115; Extreme Risiken durch weltweite Verstädterung (Extreme Risks resulting from World-Wide Urbanisation), loc. cit., p. 851.

${ }^{36}$ I.e. particular items of expenditure (such as costs of clearance, removal, or protection), loss of income and/or asset losses.
} 
The term "Trustee" was adopted because - in accordance with the basic model - all payment transactions are carried out via him and because he also administers the capital (funds) arising in the interim period. Again according to the basic model, the Trustee also makes the investment decisions during the period of availability ${ }^{37}$. When acting as the risk transfer intermediary with the insurance company, the Trustee will have a particular competency if he is himself an insurance company. Experience in active reinsurance business arising out of the transaction of both primary insurance and reinsurance would be an additional advantage and the experience of a professional reinsurer even more $\mathrm{so}^{38}$. A professional reinsurance broker is also likely to have the relevant expertise. Such intermediaries presumably increase confidence in the securitization and in the individual conditions applicable to the transfer of risk $^{39}$ even if the transferring insurance company only wishes to retain a relatively small proportion of the risk for its own account ${ }^{40}$.

Assistance in the construction of insurance-linked bonds can in particular be provided by banks and professional financial brokers with experience in placing capital market securities. Above all, experience in venture capital financing will be needed, e.g. relating to the procuring of risk capital to finance recently founded companies with a high risk/opportunity factor. Such recipients of capital cannot of course be compared to established insurance companies, seeking guarantee capital to reduce their own exposure. Nevertheless, there is a similarity in one important characteristic of the capital envisaged in both cases and this relates to its guarantee function or risk covering ability mentioned above. This leads to the same target group of investors who are the clientele of the banks and financial brokers described here and who can best be reached through their infrastructure ${ }^{41}$.

It is not necessary for all the functions described above to be assumed by one single intermediary. A number of intermediaries - each with their own specific areas of expertise - can be used instead, for example a reinsurance company or broker between the insurance company that is transferring the risk and the Trustee and a bank or financial broker ${ }^{42}$ between the Trustee and the investors. There may already be suitable companies within a financial services conglomerate or a group of cooperating financial services providers (in so far as an appropriate association exists). The use of an insurance company which is a member of a group or association as an intermediary for the transfer of risk to the capital market could be subject to certain reservations in that investors might entertain greater doubts concerning the equitable determination of insurance premiums. This is

${ }^{37}$ Alternatively, the Trustee may be responsible only for the administration alone, and thus leave it to the insurance company to determine the investment decisions.

${ }^{38}$ Shimpi discusses the possibility that a "special purpose company", licensed as a reinsurer with a minimal capital base, but managing a large portfolio of insurance-linked bonds could suitably be employed to carry out the risk transfer to the capital market. Cf. Shimpi, P.: loc. cit., p. 24.

${ }^{39}$ This applies above all to those intermediaries who are involved substantially in the valuation of risks and / or the determination of damages as independent adjusters. Cf. Müller, E.: loc. cit., p. 603.

${ }^{40}$ In addition, the Trustee may also take a certain part of the risk as a self-retention in order to increase the confidence of the investors in the insurance-linked bonds, particularly so if he is a professional reinsurance company. Cf. similarly Engeström, J.: Capital Idea, Interview with G. Booth, in: ReActions, (16) 1996, August, p. 24.

${ }^{41}$ Cf. Engeström, J.: loc. cit., p. 24.

${ }^{42} \mathrm{~A}$ bank consortium and/or several or many financial brokers could also be appointed. 
significant in so far as payments made on insurance-linked bonds should be derived directly or indirectly from insurance premiurins as well.

Apart from the need to chose the most appropriate process for the completion of the technical aspects, the Trust aspect referred to here is also a factor in determining whether - if at all - an intermediary / Trustee should be interposed between the risk transferring insurance company and the investors. Theoretically, at least, this is not absolutely necessary for securitization to function properly.

\subsection{Types of 'Insurance-linked Bonds' as risk investments}

The "insurance-link" of the bonds, i.e. the connection to the underwriting risk, can relate to the interest and/or the capital repayment entitlements which can be dependent on the number and/or the amount of incurred claims. The different types of insurance-linked bonds can be differentiated accordingly as illustrated in the following matrix:

Figure 2

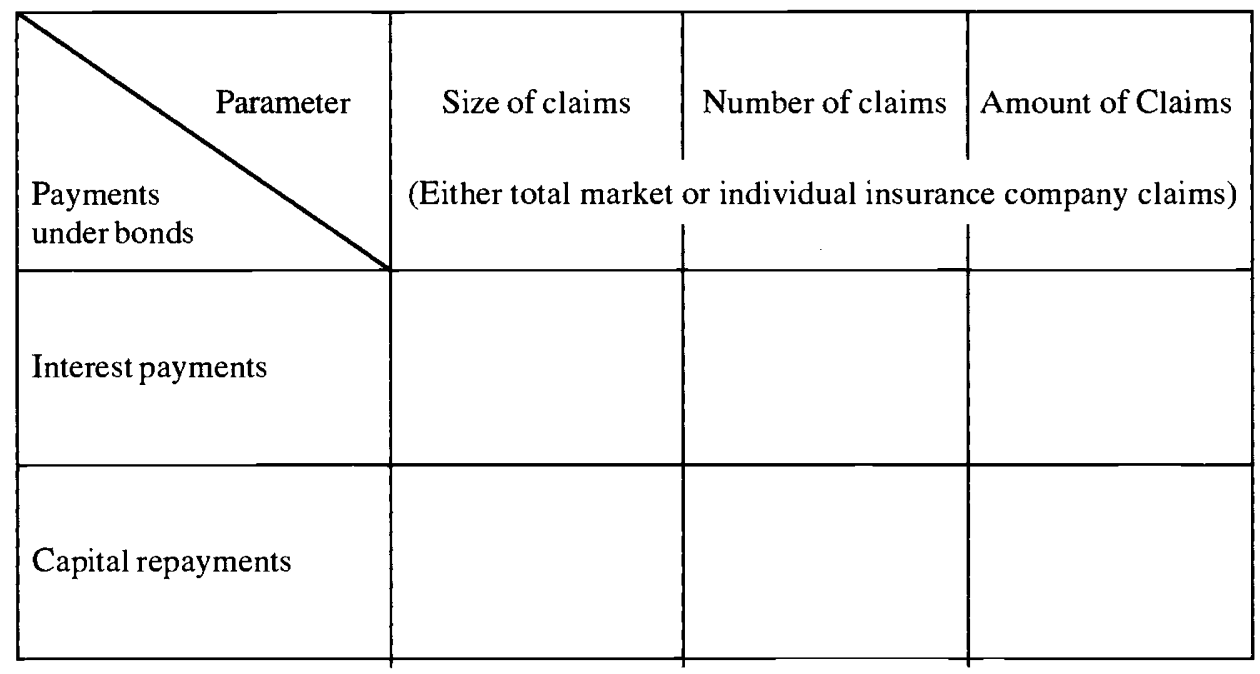

The storm risk is again considered to exemplify the transfer of risk to the capital market by means of securitization. To this end, insurance-linked bonds are issued to investors in return for the capital invested. In return the investors will have the prospect of interest income and later repayment of the invested capital. Both these can be made dependent on the occurrence or non-occurrence of storm claims, which means that the investors are assuming the on-going storm risk. For the insurance company which, having granted the cover on the insurance market, is the original carrier of this or a similar storm risk, this results in a corresponding transfer of risk. In terms of risk hedging, the degree of efficiency of this transfer, from the point of view of the insurance company, will depend on the parameters governing the interest and capital repayments, as will be illustrated below. 
The parameters for the interest and/or capital repayments under the insurance-linked bonds can be either the total market insured storm claims ${ }^{43}$ or only those that are insured by the transferring insurance company ${ }^{44}$. For the investors the market factor has the advantage of being less fortuitous; the market portfolio contains a larger number of insured storm risks and should, as a rule, present a better mixture for the purpose of risk hedging. Further, the extent of the market claims can hardly be manipulated by the individual risk transferring insurance company and it also has no significant information advantage in relation to the insured risks and the insurance premiums payable thereon ${ }^{45}$. However, the more the mix of the market portfolio differs from that of the insurance company concerned, the less efficient is the risk hedging from its point of view if the payments under the bonds depend on the total market insured storm claims. Securitization then requires the existence of a reporting system to include all insured claims of the market which is a serious burden on the overall administration. The simpler administration and the more efficient risk hedging therefore point to the adoption of the claims experience of the individual insurance company as the parameter for the interest and capital repayments under the insurance-linked bonds.

If a high degree of efficiency of risk hedging is the primary requirement, the ideal basis for payments under the bonds is the amount of claims of the individual insurance company in a given reference period. The amount of claims is the sum total of all the separate claims; it can also be arrived at as the product of the number of claims or the number of insured events and the average amount of claims. Given the following conditions, a high degree of efficiency of the risk hedging can be assumed: the full interest and, on maturity, the full capital repayment will only be payable if the amount of claims remains below a pre-defined amount. The full instalment would similarly be payable when repayment is to be made in instalments. If, on the other hand, the amount of claims

${ }^{43}$ In this connection the total market insured claims may be derived either in terms of absolute amounts or as indices, for example in the form of claims ratios. Cf. König, M.: Der Anleger als "Rückversicherer" - Alternativer Risikotransfer mittels "Katastrophen-Anleihen" nach deutschem Recht (The Investor as 'Reinsurer' - Alternative Risk Transfer by Means of 'Catastrophe Bonds' under German Law), Working paper 4/97 of the Institut für Handels- und Wirtschaftsrecht (Institute for commercial and business law), University of Osnabrück, p. 5 et seq. and Thomas, B.: Insurance Meets Wall Street, in: Risk Management, (44) 1997, No. 5, p. 17. Where overall claims ratios for the whole insurance market or sectors of the market are used as the parameters governing the interest payments and/or the capital repayments under the insurance-linked bonds, the risk transfer by securitization is very similar to the Chicago Board of Trade system of risk transfer by means of insurance index futures transactions. A clear distinction between the two systems is in this event no longer possible. Cf. also Shimpi, P.: loc. cit., p. 23.

${ }^{44}$ In theory it is possible to link to the total losses arising from single or several/many loss events, whether these are insured or not. Cf. König, M.: Der Anleger als "Rückversicherer" - Alternativer Risikotransfer mittels "Katastrophen-Anleihen" nach deutschem Recht (The Investor as 'Reinsurer' - Alternative Risk Transfer by Means of 'Catastrophe Bonds' under German Law), loc. cit., p. 5 et seq. In this case, however, the investors do not acquire 'insurance-linked' bonds as such as these no longer have an insurance basis. Further, this variation in the method of determination of the interest payments and/or capital repayments under the bonds would not be regarded by insurers as satisfactory for an efficient transfer of their insurance risk if the total losses and the insured claims were not highly enough positively correlated one with another. Lastly, there would be a major data capture problem as adequately accurate information would also be required as to the number and size of uninsured losses. It is doubtful whether such accurate information could be made available at all.

${ }^{45} \mathrm{Cf}$. also Thomas, B.: loc. cit., p. 15. 
exceeds the agreed limit, then in the first place the interest will be reduced by the amount of the "excess" claims and over and above, to the extent that this does not suffice to cover the excess claims, the repayment entitlement will also be reduced. In this way the insurance company will at least achieve perfect hedging of the (pure) risk that the insured claims incurred in a given period are in excess of the agreed limit and within the "layer of liability" of the investors. The "layer of liability" is taken to be the sum of the original interest and repayment entitlements of the investors (or if they have previously been reduced, the amounts outstanding).

The reference period need not necessarily be identical to the term of the bonds in order to achieve perfect risk hedging in the manner described. The effectiveness of risk transfer by securitization only requires that the reference period for the determination of the total interest and/or maturity payments under the bonds is not longer than the term of the bonds themselves but it can well be shorter 46,47 . For the insurance company's risk hedging, it is an advantage if the reference period (and consequently the term of the bonds) at least matches the legal term of the insurance contracts and better their term in actual practice. To this end, periods of time of less than one year or of one or more years can be advantageous in individual cases.

In order to reduce the risk to investors whilst at the same time obtaining perfect risk hedging for the insurance company in the manner described, where the bond terms extend over several years with annual interest and possibly repayment by annual instalments ${ }^{48}$, the possibility of subsequent restitution of reductions related to years of account can be agreed. This can arise, in this connection, from actual or potential reductions of interest and/or repayments resulting from excess claims in previous years of account. The restitution must accordingly be tied to the emergence of corresponding 'subnormal' claims of the insurance company in subsequent years of account. Technically stated this means that the bonds provide limited risk diversification over time in favour of the investors. The limitation may arise in two respects:

1. It is realistic to predicate that investors should not participate, by way of additions to the agreed (upper) level of the rate of interest and possible repayment, in the subnormal claims of the insurance company occurring in the period of time before possible excess claims. Consequently, in the subsequent years there are no surplus amounts available to be set against reductions in payments resulting from corresponding excess claims. The risk diversification over time therefore predicates, and is thereby limited, that the excess claims and the resulting reductions in payments arise first, and only thereafter the subnormal claims which lead to the restitution of the previously reduced payments.

2. The risk diversification over time is only effective over the limited term of the insurancelinked bonds. To the extent that payment reductions arise at the end of the term or have not previously been restored, they accrue conclusively to the disadvantage of the investors. In that event at the latest the bond risk thereby crystallises.

\footnotetext{
46 This could in fact be desirable having regard to the time required to establish the actual incurred claims.

${ }^{47}$ The reference period for the determination of current interest should by analogy be at most as long as the related interest period i.e. it should terminate at the latest at the end thereof.

${ }^{48}$ The alternative is payment of the total interest and capital entitlement at the end of the term of years. In this event the subsequent discussion is irrelevant.
} 
So far it has been assumed that investors are fully liable under the insurance-linked bonds to the extent of their total interest and repayment entitlements. The bond risk can however be reduced by means of various limitations on the possible entitlement reductions more certainly than by the expectation of risk diversification over time. The following variations, listed in descending order of the risk to the investor, are conceivable:

- In principle the investors are liable in the event of relevant excess claims under the insurance transactions as to their interest and repayment entitlements. However, only the interest can be totally lost and the repayments can only be reduced to a defined level. Thus the capital repayment to the investors is fixed as a minimum amount below the level of their original capital investment.

- Investors are liable in the event of excess claims under the insurance transactions only in respect of their interest entitlements, albeit as previously without limit. On maturity the investors at least receive back their invested capital in full.

- Investors are liable in the event of excess claims under the insurance transactions only in respect of their interest entitlements, and only to a limited extent. Thus a minimum rate of interest is guaranteed to the investors in addition to the return of their capital in full $49,50,51$.

As excess claims under the insurance transactions increase, the reductions in the investors' entitlements can either be continuous or in graduated stages as each staged level of excess claims is passed.

${ }^{49}$ This explains the reference in the basic model to the repayment entitlements being conditional or unconditional. Cf. in this connection König, M.: Der Anleger als "Rückversicherer"-Alternativer Risikotransfer mittels "Katastrophen-Anleihen" nach deutschem Recht (The Investor as 'Reinsurer' - Alternative Risk Transfer by Means of 'Catastrophe Bonds' under German Law), loc. cit., p. 3 et seq, and Müller, E.: loc. cit., p. 601. However the variation that, in the event of excess claims under the insurance business, only the repayment entitlements but not the interest entitlements would be reduced, is at most of theoretical interest and should not be relevant in practice.

${ }^{50}$ In context with the different variations it should be taken into account that the investors' liability as to their invested capital immediately creates risk coverage capacity in a corresponding size, whereas a liability as to the claims of interest only creates capacity equal to the cash value of the future deductible interests. Cf. Müller, E.: loc. cit., p. 602.

51 The following are two special cases of the investors' liability: 1 . The rate of interest would be guaranteed for so long as no relevant excess claims arise, thereafter it would be reduced downwards towards the minimum rate (or nil as the case may be) only for the remainder of the term of the bonds. For example cf. Kielholz, W.; Durrer, A.: loc. cit., p. 8 et seq. However the (remaining) term of the insurance-linked bonds and the (remaining) period of interest payments can well be longer than the remaining investors' duration of liability. Given a certain amount of bonds issued, the liable capital will be then increased compared to the case of an interest payments period identical with the investors' duration of liability. Cf. Müller, E.: loc. cit., p. 602.

2.

A completely different construction would be that the creditors' rights to interest and repayment could be converted into participation rights in the insurance company

- in the event of excess claims and/or possibly also

- without limiting conditions during the term of the bond or on maturity.

Cf. Punter, A.: An Engagement is Announced, loc. cit., p. 8. This can be achieved by constructing the insurance-linked bonds as convertible bonds. In so far as the bonds are converted into participating securities in the event of excess claims, the liability of the investors is expressed in a simultaneous fall in the value of the securities. 
The less (greater) the risk to the bond-holder consequent on one of the variations in construction described above, the lower (greater) should be the base rate of interest the investors require for their investment ${ }^{52}$.

If the risk is reduced in favour of the individual investor by one of the foregoing variations, this does not imply that the insurance company must necessarily retain part of the risk itself. If the amount of bonds issued is large enough, the total interest and/or repayment reductions risked by all investors can be precisely as great as the amount of capital risked by the insurance company in the insurance transactions. The amount of the issue necessary to achieve this can be calculated exactly as a defined multiple of the capital at risk under the insurance transactions depending on:

- the construction of the insurance-linked bonds, i.e. the relationship of the amount of the potential reductions in interest and/or repayments to the respective nominal amount,

- the level of the insurance premiums that the risk transferring insurance company pays and

- the expected returns (in the form of yield and repayments) from the capital investments undertaken by the Trustee $53,54,55,56$.

Investors may view the linkage of the bond risk to the amount of claims on the insured risks with some suspicion for the following two reasons: In the first place this parameter, governing possible reductions in investors' entitlements, is comparatively nontransparent; secondly it can, to a certain extent, be manipulated by the insurance company.

52 The agreed maximum rate of interest can then be regarded as the "base rate of interest", which in the favourable event of only a few or even no claims and/or only small insured claims is expected. Thus, in fact, taking into account the variable repayment entitlement, there is a range of possible rates of interest or yields within which the actual yield will lie depending on the claims result. The lesser (greater) risk to the bond holder is thus expressed in a range of smaller (larger) yields under the various different construction forms. Cf. in this connection the numerate examples in Shimpi, P.: loc. cit., p. 25. Further, bonds based on the same insured risks can also be structured by the issuer so that several tranches may be issued at the same time which differ from each other only in terms of the investors' liability (in the sense of varying degrees of possible reductions or minimum levels of repayment and/or interest entitlements) and the consequent bond risk.

53 ... or by the insurance company itself ...

${ }^{54}$ In the case of given limitations of the possible reductions in entitlements according to the periods, the calculation can not be made over the total term of the bonds without differentiation. Instead, each period must be considered separately in particular having regard to the relationships of the possible interest and/or repayment reductions to the nominal amount of the issue. The nominal amount must then be great enough to cover the maximum possible excess claims in each single period.

$55 \mathrm{Cf}$. the numerical example by Heri, E. W.; Frost, P.: Versicherungsrisiken an den

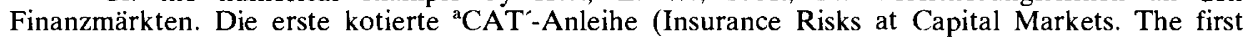
official listed ' ${ }^{a}$ CAT'-Bond), in: Asset Management: Finanzdienstleistungen von und für Versicherungen, published by E. Henn, Stuttgart 1998, p. 172. In this example the volume of issues of a "principal protected cat bond", which is required to securitize a "layer" of 100 million monetary units, is calculated $\tilde{n}$ based on the assumption that the repayment of the whole capital is guaranteed and that the investors are liable only as to their interest entitlements. Supposing an interest rate of $3 \%$ per annum the requirement amounts to 3.3 billion monetary units. Cf. alluded to also in Ballantine, $R$. Bonding Experience, loc. cit., p. 93 and Kielholz, W.; Durrer, A.: loc. cit., p. 9 et seq.

56 From the point of view of cost effectiveness, Gonseth considers the minimum amount to be "tranches of USD 10 to 20 million"; he does not however disclose how he arrives at these amounts. Cf. Gonseth, M.: loc. cit., p. B11. 
This arises from the degree of flexibility the insurance company has in the necessary estimation of the amounts of claims arising under the many insured events. Of particular concern are the claims reserves which can be estimated higher or lower and thus give rise to higher or lower excess claims determining the reductions in investors' entitlements under the insurance-linked bonds.

Against this background it can be advantageous to link the bond risk to the number of claims alone. The number of insured claims is a parameter which is comprehensible to investors and at the same time largely free from the possibility of manipulation by the insurance company. However, in this event, only one specific element of the underwriting risk will be transferred via the insurance-linked bonds to the capital market and that is the risk of a (fortuitous) exceptionally high claims frequency. To a greater or lesser extent, the size of claims risk will still be borne by the insurance company. Depending on the make-up of the insurance portfolio as indicated by its typical claims structure, this implies little efficiency of hedging of risk. Above all, if the total amount of claims is less influenced by a greater or lesser number of small or medium-sized claims than by the occurrence of one or a few large claims or none, then, from the point of view of the insurance company, the number of claims is hardly a suitable parameter for hedging risk. In such a case the large claims risk or catastrophe risk under individual insurance contracts dominates and can be more efficiently transferred to the capital market if the respective size of claims is the factor which determines reductions in interest and/or repayment entitlements under the insurance-linked bonds.

On the other hand the number of claims is a particularly suitable determining factor, if the accumulation risk in an insurance portfolio, or section thereof, is of overwhelming significance. The risk of a fortuitous accumulation of small and medium-sized claims arising from many individual risks where correlation of risk cannot or can scarcely be envisaged, can be transferred effectively to the capital market. The theft risk in some sectors of the motor vehicle comprehensive insurance business can be cited as an example of accumulation which first became apparent following the opening of borders in Eastern Europe.

If the possibilities for accumulation of insured claims dominate owing to the fact that many or all of the individual insured risks in an insurance portfolio are recognised in advance as being exposed collectively to particular causes of claims, the number of causative claim events can be a useful alternative to the number of individual claims as the parameter. Once again this can be illustrated by reference to storm claims to which all risks with storm cover within a storm zone are exposed. In order to transfer the inherent accumulation risk to the investors, their interest and/or repayment entitlements under the insurance-linked bonds could be made dependant upon the number of storms occurring during the reference period, i.e. they could be reduced if a pre-determined frequency of storms is exceeded. Graduated reductions whereby, as and when the upper frequency limit of each defined stage for the event concerned is exceeded, a further reduction in the interest and/or repayments comes into effect would, by analogy with the foregoing, also be possible 57

${ }^{57}$ For numerate examples cf. König, M.: Der Anleger als "Rückversicherer" - Alternativer Risikotransfer mittels "Katastrophen-Anleihen" nach deutschem Recht (The Investor as 'Reinsurer' - Alternative Risk Transfer by Means of 'Catastrophe Bonds' under German Law), loc. cit., p. 3 et 
For the investors, the number of claim events is also an understandable and ascertainable factor which should encourage their acceptance of it as the parameter determining the entitlements under the bonds. On the other hand there is not necessarily an appropriately high degree of positive correlation between the number of claim events and the total amount of the insured claims which renders the efficiency of the risk hedging to some extent questionable from the insurance company's point of view. Taking this example further, individual storm events may vary widely in their extent from region to region and produce greater or lesser wind forces - with the obvious result of varying amounts of claims; these can also be significantly influenced, inter alia, by the wind direction. In such cases the insurance company might link the claims events to defined minimum claims amounts as the determining factors for the reduction of entitlements under the insurance-linked bonds in order to transfer the peaks of the accumulation risk, in particular, to the capital market. Albeit estimates of size of claims would then again be necessary, which would give rise to the problems already discussed. However as in this connection it is only a matter of determining whether the minimum claims amount is exceeded or not, only the - presumably infrequent - marginal cases would give rise to question.

\subsection{Types of investors in "Insurance-linked bonds"}

In principle, every type of investor to be found in the capital market is a suitable investor in "insurance-linked bonds". This also includes (other) primary insurance or reinsurance companies with appropriate available capital and spare capacity to accept the risks in question. However, insurance companies that invest in insurance-linked bonds hardly increase total risk coverage capacity from an overall economic point of view. In this instance it is more likely that such insurers would be shifting their individual underwriting capacities away from traditional primary insurance or reinsurance towards a quasireinsurance based on a financial approach ${ }^{58}$.

Apart from this, it is above all banks and investment companies, including provident funds ${ }^{59}$, wishing to diversify their investment portfolios - that can be identified as potential investors. It could be advantageous to them that there is virtually no correlation between those risks relating to insurance coverage and therefore to insurance-linked bonds and the usual investment risks (market price risks, interest rate risks, currency risks) ${ }^{60}$. According to modern portfolio selection theory, an overall investment portfolio of a bank or investment company can be more efficient from the risk/return point of view when based

58 This mainly applies to Property \& Casualty insurance companies. Life insurance companies and also health insurance companies investing in insurance-linked bonds would do so, not in order to utilise surplus capital but to spread their capital investments according to the principles of 'mixing and spreading'.

${ }^{59} \mathrm{Cf}$. also Shimpi, P.: loc. cit., p. 22 and Vukelic, M.: loc. cit., p. 18 with reference to 'mutual funds' and 'pension funds'.

${ }^{60} \mathrm{Cf}$. anon.: Fortschreitende Verbriefung von Versicherungsrisiken (Progress in Securitization of Insurance Risks), in: Neue Zürcher Zeitung, 23. August 1996, p. 24; Clow, R.: loc. cit., p. 138; Figge, F.: loc. cit., p. 10; Geman, H.: loc. cit., p. 3; Gonseth, M.: loc. cit., p. B11; Heri, E.W.; Frost, P.: loc. cit., p. 169 and 171; Müller, E.: loc. cit., p. 597; Punter, A.: An Engagement is Announced, loc. cit., p. 8; Shimpi, P.: loc. cit., p. 22; Smith, R. E.; Cancelo, E. A.; Di Dio, A. M.: loc. cit., p. 31 and Thomas, B.: loc. cit., p. 15. 
on a combination of investment types including insurance-linked bonds ${ }^{61,62}$. However, a large volume of investment based on securitization is not to be expected from such investors, due to the high-risk nature of insurance-linked bonds - if they are in a form that places relevant liabilities on the investors - and the lack of experience in such investments ${ }^{64}$.

Apart from the large institutional investors, who in reality are currently the principal interested parties (at least so far) ${ }^{65}$, private investors also come under consideration ${ }^{66}$. Although the majority of the latter can only provide comparatively small investment amounts, given sufficient numbers these can nevertheless add up to a considerable sum. If sooner or later it becomes possible to make insurance-linked bonds attractive to the broad

61 In other words: By the addition of an appropriate quota of insurance-linked bonds to the existing portfolio of investments the expected value of the portfolio yield can be increased and/or the yield risk as measured by the standard deviation or variance of the portfolio yield can be reduced. Cf. Ballantine, R.: Capitalising on Risk, loc. cit., p. 90; Durrer, A.: loc. cit., p. 1199 et seq.; Groth, C. H.: A Rising Tide? The Converging Capital and Insurance Markets, in: Risk Management, (44) 1997, No. 2 , p. 20 et seq.; Heri, E.W.; Frost, P.: loc. cit., p. 171; Punter, A.: Something out of the Ordinary, loc. cit., p. 18; Smith, R. E.; Cancelo, E. A.; Di Dio, A. M.: loc. cit., p. 31; Vukelic, M.: loc. cit., p. 18 and more extensively Kielholz, $W . ;$ Durrer, A.: loc. cit., p. 11 et seq., who underline their theoretical considerations with the results of simulations in the context of an optimisation model.

62 Enterprises, for example repair enterprises, which "profit" from the occurrence of insured risks but make little or no income 'if nothing happens' could, by acquiring appropriately constructed insurance-linked bonds, take on an investment risk which is negatively correlated with their normal business risk. Thus they would achieve not only risk diversification but also, over and above this, an element of risk hedging. This aspect is however only of theoretical relevance as, in the types of enterprises here under consideration, the necessary insight and/or capital assets for the purposes of such investment would not be available.

${ }^{63} \mathrm{~A}$ further high risk arises from the fact that falls in the values of insurance-linked bonds, arising from reductions in the entitlements as a result of catastrophic events, generally presage ultimate losses for the investors (in so far as, in the event of the insurance company experiencing 'subnormal' claims in subsequent periods, full restitution of the reductions is not possible). Conversely, falls in value of traditional investments resulting from price fluctuations on the capital markets are not - or not immediately - realised and can often be recovered later.

${ }^{64}$ Durrer, A.: loc. cit., p. 1199 cites the following counter-argument: "Capital investors in (re)insurance shares have always indirectly participated world-wide in catastrophe risks. But, willynilly, they thereby carry not only the insurance companies' liability risks but also their asset risks: i.e. including those of their financial investments whose price fluctuations are linked to economic and stock exchange performance" (Remark: This is originally a German quotation. Here and in the following German quotations are translated into English). Cf. also, almost identically, Kielholz, W.; Durrer, A.: loc. cit., p. 8 et seq. and similarly Smith, R. E.; Cancelo, E. A.; Di Dio, A. M.: loc. cit., p. 28, who emphasise that the shareholders of insurance companies are not only exposed to the insurance risks but also, in addition, to all other entrepreneurial risks. Conversely, investors in insurance-linked bonds are exposed only to the insurance risks and only to the extent provided by the parameters governing the interest and/or repayment entitlements. The more or less narrow limitation of the parameters in securitization in effect means a "disaggregation of risks" that are transferred to the capital market in isolation. In this connection, there is seen to be an advantage for the investors in that they are more able to evaluate the profile of isolated insurance risks than e.g. the overall risk of an insurance portfolio possibly comprising a mix of very different insurance perils, objects and/or types of loss. Cf. ibid., p. 30.

${ }^{65}$ Cf. Durrer, A.: loc. cit., p. 1198 et seq. and Kielholz, W.; Durrer, A.: loc. cit., p. 4 et seq. This probably applies as long as the securitization market is not very liquid. Cf. Shimpi, P.: loc. cit., p. 22.

${ }^{66} \mathrm{Cf}$. Figge, F.: loc. cit., p 10. 
mass of investors by combining limited risk exposure and an attractive rate of interest, a considerable expansion of capacity could be achieved as a result ${ }^{67}$.

It is difficult to judge whether many speculators will be attracted to the overall group of investors. On the one hand, the risk/return profile of investments in insurance-linked bonds would generally appear to be relatively strongly marked when seen over the whole term. High yield volatility in conjunction with high yield expectations should find favour with speculative investors. On the other hand, very short term profit prospects tend to be slight. Major price movements in the secondary market - that would itself first have to develop - can only be imagined as being "downwards" in the event of insured losses (and their immediate impact) that will reduce the interest and / or repayment entitlements of the bonds. The absence of such losses will only gradually lead to price increases over time, at best immediately prior to the expiry date of the bonds to a level where, from the point of view of a potential buyer, the yield to maturity including the fixed nominal rate of interest would equate to that of a risk-free investment ${ }^{68}$.

In addition to the question regarding which types of investors - apart from insurance companies - can be taken into consideration, it is also essential to determine what they require from insurance-linked bonds in order actually to invest in them. Excluding typical equity capital providers of insurance companies as investors, some of the general requirements of buyers of bonds are as follows: 69

- The (insurance) risk being transferred under the bonds should be of an unambiguous, constant and demonstrably defined nature, restricted to a maximum value and also diversifiable.

- In addition the investor should be able to evaluate it, so that he can also determine the fair value of his bonds himself.

- There should of course be the prospect of an appropriate risk / return ratio.

- As has already been mentioned above, there is one further requirement - at least in respect of those bonds with longer terms - that is not met at all. This refers to the existence of a liquid secondary market where bonds can be traded and therefore also sold during their terms.

${ }^{67}$ It would possibly be attractive - particularly but not exclusively - to private investors to participate in an investment fund comprising various insurance-linked bonds under which the catastrophe risks were independent of each other. Even catastrophe risks covered by smaller amounts of investment would in this way themselves be diversified. The author is not however aware that any such investment funds have been set up to date. (In a business periodical mention is made of such a project of the Zurich Überseebank for the end of 1996; cf. Jahn, T.: loc. cit., p. 152. However there is no knowledge of the realisation of this project.)

${ }^{68}$ The above remarks are based on a background of an essentially efficient market for insurancelinked bonds. If however market inefficiencies lead to departures from 'fair prices' speculators or rather arbitrageurs would be attracted thereto in large numbers. In turn their transactions would tend to influence prices towards the 'fair' level and thus improve the market efficiency. But the speculators / arbitrageurs would thereby provide little additional capital for the coverage of risks. Cf. Shimpi, P.: loc. cit., p. 22.

${ }^{69}$ Cf. Shimpi, P.: loc. cit., p. 21; Smith, R. E.; Cancelo, E. A.; Di Dio, A. M.: loc. cit., p. 29 et seq. and Vukelic, $M$. loc. cit., p. 18. 


\section{Risk securitization vs. traditional reinsurance: $\mathbf{A}$ critical comparison}

From the consideration of risk, the positions that an insurance company achieves by means of traditional reinsurance on one hand and by risk transfer through risk securitization on the other are similar. Proceeding from the risks initially taken up from the insurance market, each results in a form of risk hedging. An important difference lies in the procedure adopted which is either of a technical insurance nature (reinsurance) or of a financial transaction nature (securitization). Because of the similar impact on the risk, a comparative analysis from the point of view of the insurance companies is called for ${ }^{70,71}$.

In this regard, securitization can be of value as a means of risk transfer for the following considerations:

- Depending on the construction of the insurance-linked bonds, the total underwriting risk or particular aspects thereof can be transferred. Thus, for example, the claims frequency risk and in particular the accumulation risk within insurance portfolios or sections thereof can be transferred separately to the investors. The same applies to the claims size risk, in particular the large claims risk or the catastrophe risk of individual insured risks. If the particular risks are dominant in the insurance cover assumed, the desired hedge effects will be obtained. The prerequisite is a sufficiently high positive correlation between the claims amount - or more precisely the possible excess claims within the insurer's own portfolio of risks and the resulting reduction of interest and/or repayment entitlements under the insurance-linked bonds. Such correlation can well be established with parameters based on the company's own claims experience governing the investors' entitlements. A high positive correlation is questionable if total market parameters are applicable, particularly in the case of a small risk-transferring insurance company with a special portfolio mix not typical of the market ${ }^{72}$.

- Consequent upon the relatively small volumes of individual bond issues, the amounts of the transactions can be divided up conveniently and accommodated to the individual volumes of the insured risks. Thus in so far as the amounts at risk are concerned perfect hedging can be obtained. However in this respect a deliberate incomplete hedge position can also be achieved ${ }^{73}$.

- Only a limited disclosure of the portfolio construction, the risks insured, the insurance conditions and the insurance premiums needs to be disclosed to the investors, whereas

${ }^{70}$ The following comparison is restricted to risk aspects. Other aspects such as accounting and taxation are not considered.

${ }^{71}$ A comparative assessment according to the method of production of insurance protection is concerned not only with risk transfer by the effecting of reinsurance but also e.g. with covering of risk by way of shareholders' equity. Shimpi, P.: loc. cit., p. 25 makes reference hereto in considering the cost of capital.

72 It follows that, for such an insurance company, securitization is of doubtful value where it is based on market indices which serve as the vehicle for risk transfer not only for that insurer but also for a whole range of insurance companies.

${ }^{73}$ If there is complete positive correlation between the excess claims under the insurer's own portfolio of insured risks and the reduction of interest and/or repayment entitlements under the bonds, then the issue of a lesser amount of bonds than would be required for perfect hedging of risk will result in an overall risk situation similar to that under a passive quota-share reinsurance with a reinsurance factor less than $100 \%$. 
the requirements of disclosure to a reinsurer are likely to be more extensive. On the other hand, in every case the investors must be furnished with clear and plausible descriptions of the mechanism and the conditions whereby reductions in their entitlements arise and of the pricing i.e. of the basis of the issue price of the insurancelinked bonds. In this respect the provision of adequate information concerning the insurance relationship is indispensable ${ }^{74}$.

- Additional liabilities for payments by the insurance company to the investors over and above the agreed interest and repayment - such as e.g. additional premiums due to the reinsurer - can not in any circumstances arise, even if particularly many and/or large claims subsequently arise.

- In relation to the investors, the risks of default do not arise as they subscribe the capital covering the insured risks in advance ${ }^{75}$. In place of the credit risk of reinsurance companies there arises the credit risk of the Trustee, where applicable. This however should be relatively less if and to the extent that the Trustee is not himself a risk carrier. Finally, the risk to the insurance company of a shortfall of yield or capital ${ }^{76}$ in respect of the further investment of the insurance premiums and the investors' capital received which he himself or the Trustee has undertaken does however always remain ${ }^{77}$.

- If the proceeds from the sale of the insurance-linked bonds are received directly by the insurance company (and not in the first place to an intermediary Trustee who undertakes the further investment on the capital market) there will be a direct positive effect on its liquidity ${ }^{78}$.

- With the corresponding term to redemption or term of the liability of the bond, it is possible to secure a longer period of protection than one year from the outset. The yearly renewal or renegotiation of contracts which is usual with reinsurance is thus avoided ${ }^{79}$

- The positions assumed with the emission of bonds can be closed out by repurchases assuming that an adequately liquid secondary market exists. This increases the flexibility of the insurance company. Repurchases will of course be effected at the ruling market prices. If the actual claims to date are less than the expected claims, the repurchase price should tend to be higher than the issue price.

- Conversely, additional bonds can be issued subsequently, for example if the volume of insurance business has increased and/or if in the meantime particularly many or large

74 The advantage of a limited (factual) disclosure requirement presumably does not apply if a competent, independent Trustee is interposed between the insurance company and the investors, as he should demand the same information for his assessment as would a traditional reinsurer.

${ }^{75}$ Cf. Müller, E.: loc. cit., p. 600.

${ }^{76}$ Reduced repayments can arise either on the maturity of investments or in the event of sales at decreased rates.

77 Whether the insurance company is actually affected thereby will depend on the construction of the securitization contract. In particular, it will depend on how the liability for the investment risk is apportioned between insurance company, the investors and the intermediary Trustee (if any).

${ }^{78}$ Cf. Brooks, K. H.: loc. cit., p. 126.

${ }^{79} \mathrm{Cf}$. ibid. 
claims have arisen. In the latter event however regard must again be had to alterations in the market price. The daily price of the bonds in issue would have fallen correspondingly. If the other factors relating to the new bonds remain unaltered the effective issue price will be similarly reduced with the result that the proceeds to the insurance company for each bond issued will be reduced ${ }^{80}$.

- The hedging effect which can be achieved by securitization can increase the underwriting capacity of individual insurance companies and of the whole insurance market as seen from the commercial and risk-theory viewpoint. Moreover, the deployment of the additional capacity in writing a larger number of insured risks results in a better spread of risk in the underlying insurance portfolio if the insured risks, including the new business, are sufficiently unrelated.

Significant problems, limitations and disadvantages of risk transfer by securitization are as follows:

- Owing to the absence of standardisation, the risk transfer must be newly structured and organised from case to case. The administrative work thereby involved is considerable. This includes, inter alia, the definition of the full conditions of the insurance-linked bonds, the construction of a consortium of banks, where applicable, for the issue, the drafting, finalisation and distribution of the issue prospectus and finally the placing of the bonds. Consequently, the risk transfer involves a greater amount of time and higher transaction costs ${ }^{81,82}$. Furthermore disturbing is the usually high complexity of a risk transfer contract tailor-made for the capital market ${ }^{83}$.

- Once the insurance company has entered into risk positions with securitization and the issue of bonds, these as such can hardly be altered to adapt to the risk development of the insurance business; as it is unlikely that the conditions attached to the bonds can be amended during their currency. The only apparent possibility is to repurchase the bonds in order to close out the risk position. A gradual alteration of the risk positions vis- $¥$-vis the investors is however conceivable by repurchasing old bonds and the simultaneous issue of new insurance-linked bonds with appropriately amended conditions.

- No subsequent liability can be placed on the investors. After the maturity of the insurance-linked bonds and the repayments thereupon, the risk of further claims from the insurance business falls on the insurance company alone. At least the belated claims risk and the risk of later loss development fall on the insurance company in toto, to the extent that it is not covered by provisions.

- At present it is completely unclear whether the sale of insurance-linked bonds and the risk effect thereof will be taken into account in the assessment of solvency or not ${ }^{84}$. In

${ }^{80} \mathrm{It}$ is as yet unclear how the capital market will react to the first "major catastrophe". Cf. anon.: Spreading Catastrophe Risk through Reinsurance and Capital Markets Reviewed at Joint Industry Forum, in: Insurance Research Letters Americas, 1997, No. 3, p. 6. In particular it is an open question whether it will be limited to price adjustments (rate-reductions) or whether the investment demand for insurance-linked bonds will thereby be curtailed, temporarily or permanently. The first bigger catastrophe can therefore be regarded as a kind of a "stress-proof" for the securitization concept. Cf. Müller, E.: loc. cit., p. 604.

81 ... inter alia in the form of "various bank and legal fees" ...; Brooks, $K . H$. loc. cit., p. 126.

${ }^{82}$ Cf. also Thomas, B.: loc. cit., p. 16.

${ }^{83}$ Cf. Müller, E.: loc. cit., p. 603 .

${ }^{84}$ Cf. Durrer, A.: loc. cit., p. 1199 and Kielholz, W.; Durrer, A.: loc. cit., p. 10. 
the worst case, neither will the required solvability of the insurance company be reduced on account of the related transfer of risk nor will the asset solvability be increased on account of the capital subscription by the investors. In such circumstances, from the legal point of view, the underwriting capacity can not be increased by securitization, which presents a considerable disadvantage ${ }^{85,86}$.

- The market for securitization business is, as yet, not very developed, the volumes of business to-date have not been significant ${ }^{87}$. An obstacle to further development lies in the probable small number of investors who are at present prepared to purchase insurance-linked bonds and thus participate in the small volume of investments actually available. Information deficiencies in individual cases ${ }^{88}$ and the general lack of investor familiarity with this type of investment and the related insurance technicalities could be important grounds in this respect. No certain prognostications can be made as to the potential for development and the possible future use of securitization by insurance companies $^{89}$.

85 If the 'insurance link' of the bonds extends over the whole portfolio of insured risks of the insurance company, it is conceivable that the sale of the bonds could be further structured in such a way that the additional capital so raised might be regarded as capital backed by warrants or subordinated loan capital under $\$ 53 \mathrm{c}$ of the VAG (German Insurance Supervisory Law). In that event it could be regarded as available free reserves for supervisory purposes.

For more extensive treatment of the effect of the transfer of risk by securitization on solvability see König, M:: Der Anleger als "Rückversicherer" - Alternativer Risikotransfer mittels "Katastrophen-Anleihen" nach deutschem Recht (The Investor as 'Reinsurer' - Alternative Risk Transfer by Means of 'Catastrophe Bonds' under German Law), loc. cit., p. 11 et seq. Here, König takes the line that, analogous to the effect of reinsurance, a deduction from the solvability requirements also arise if (as a simplification) the investors are liable to the extent of their invested capital as determined by the claims amount as described above. In this case the situation of the investors is identical to that of reinsurance companies, which also argues for equal treatment of the two forms of risk transfer under the solvability regulations. This economic argument is correct. However it is questionable whether it is compatible with $\S 1$ para. II of the Kapitalausstattungsverordnung (German Capital Requirement Regulation) for Property \& Casualty insurance companies and Health insurance companies which limits the self-retention proportion according to defined accounting values, i.e. the relationship of 'net incurred claims' to 'gross incurred claims'. At least according to the general understanding, the 'net incurred claims' are after reinsurance. Cf. also the definition in Rundschreiben R 3/88 des Bundesaufsichtsamts für das Versicherungswesen (Circular R $3 / 88$ of the German Federal Insurance Supervisory Office) with comments on the calculation of the solvency margin and the demonstration of the free reserves in accordance with $\S 53 \mathrm{c}$ para. 4 of the VAG (German Insurance Supervisory Law) and including a specimen solvability statement with explanations, in: VerBAV, 1988, particularly pages 198 and 202.

${ }^{86}$ Apart from this, it is still questionable whether German (primary) insurance companies are permitted to issue insurance-linked bonds under the present supervisory regulations or whether - as Jahn, T.: loc. cit., p. 152 suggests - this represents non-insurance business which is forbidden. If it is not non-insurance business, the question could arise whether the purchasers of insurance-linked bonds themselves are to be regarded as insurers and thus subject to the insurance supervision.

${ }^{87}$ Cf. Punter, A.: Something out of the Ordinary, loc. cit., p. 18.

${ }^{88} \mathrm{Cf}$. Thomas, B.: loc. cit., p. 16: "Investors ... are at an informational disadvantage in comparison to the insurer that underwrites the specific insured risks and pays the claims."

${ }^{89}$ Nevertheless, a number of practicians reckon that, at least in the long run, a "robust market" will develop for risk transfer by securitization, which will cover a larger volume of insured risks. Cf. Durrer, A.: loc. cit., p. 1200 ("Supported by our model calculations and a survey of investment banks and potential investors, in the longer term we can expect additional risk capital for the coverage of US catastrophe risks of the order of USD 30 to $40 \mathrm{bn}$."). Almost word for word also in Kielholz, W.; Durrer, $A$.: loc. cit., p. 14 and also Gonseth, $M$. : loc. cit., p. B 11 (who foresees "at the present time, a potential of approx. USD 50 bn. per annum" - but presumably based on world-wide risk coverages and 
In general, reinsurance is free from these problems. In part it produces the same or a similar benefit as risk transfer by securitization and in addition a number of specific advantages:

- In principle, reinsurance is appropriate, and is available, for all types of insurance risks.

- Reinsurance can also be individually tailored to the risk characteristics of the portfolio of insured risks concerned, having regard to the particular situation of that insurance company ${ }^{90}$. First and foremost is the availability of the different forms of reinsurance and their combination, some of which are suitable for the transfer of particular aspects of underwriting risk. The most efficient reinsurance program can be selected in the light of the initial portfolio of insured risks.

- By agreement with the reinsurance partner, the reinsurance cover may be altered during its term and so adapted to the development of the risks insured in the portfolio.

- The amount of the risk transfer can be controlled by reinsurance better than by means of the sale of insurance-linked bonds - particularly if the bonds may have to be offered in large numbers with small nominal values to a wide range of investors. For, whilst the more or less uncertain purchasing behaviour of a large number of investors has to be influenced, with reinsurance as a rule the desired amount of risk transfer requires only agreement with one or a few reinsurers. By means of appropriate agreements as to the levels of retention, the size of the layers of liability and similar quantitative parameters of the reinsurance cover, hedge positions of greater or lesser precision can be specifically constructed as well.

- Normally, the reinsurance covers the claims of one year. The extent of the reference period thus corresponds to a normal period of insurance. To the extent that the business period of the risk transferring insurer and the reinsurance period do not correspond, continuity of cover can be secured in practice through portfolio entries and withdrawals of the reinsurance company.

capital providers); anon.: Spreading Catastrophe Risk through Reinsurance and Capital Markets Reviewed at Joint Industry Forum, loc. cit., p. 6; Jahn, T.: loc. cit., p. 152; Levin, A. M.; Elkind, C. K.: Solutions in Search of a Problem, in: ReActions, (17) 1997, June, p. 44 et seq. and alluded to in Clow, $R$.: loc. cit., p. 142. The 'soft' reinsurance market, marked as it is by comparatively low levels of premiums in the catastrophe risks sector, is certainly an obstacle to the further development of the market at the present time. Cf. Banham, R.: loc. cit., p. 64.; Challis, S.; Booth, G.: Cat Bond Bounce?, in: ReActions, (18) 1998, April, p. 20 and Müller, E.: loc. cit., p. 604. Better elucidation of potential investors in relation to the technicalities of risk transfer by securitization is unavoidable, more particularly regarding the technicalities of the price structure which must be recognised as fair. The performance advantages - measured by the risk/yield position of the overall investment portfolio which can be achieved by the purchase of insurance-linked bonds must be as obvious to them as the risks inherent in the bonds themselves. Cf. again Kielholz, W.; Durrer, A.: loc. cit., p. 14 and also Müller, E.: loc. cit., p. 602; Smith, R. E.; Cancelo. E. A.; Di Dio, A. M.: loc. cit., p. 30; Vukelic, M.: loc. cit., p. 18 and see Palan, D.: loc. cit., p. 185 (who not only ascribes the reluctance of investors to their lack of understanding of the price structure by the insurer, but further suggests that the resulting prices are simply not fair). In this context a better transparency of the setting of prices and the claims adjustment as well as improved possibilities of control for the investors are suggested as further requirements for the future development of the securitization market. Cf. Heri, E. W.; Frost, P.: loc. cit., p. 172. At the same time it is considered that some initial successful placings and the emergence of various versions of insurance-linked bonds would stimulate further market development, on the assumption that this would lead to a larger number of investors becoming interested in such investment securities. Cf. Ballantine, R.: Bonding Experience, loc. cit., p. 93 and Shimpi, P.: loc. cit., p. 25.

${ }^{90}$ For a tabular contrasting of the characteristics of reinsurance and securitization, cf. Kielholz, W.; Durrer, A.: loc. cit., p. 10. 
- Claims that eventually arise within the reinsurance period are covered. Late notified claims are thus also specifically included.

- One of the consequences of the frequently long-lasting business relationships is that the results of the reinsurance treaties are subject to a degree of risk diversification over time $^{91}$. Having regard to this factor in the calculation of the reinsurance price, the reinsurance premium, or more precisely the security loading included therein, can be comparatively lower than the risk related interest surcharge on the insurance-linked bonds ${ }^{92,93}$.

- To the extent that the reinsurance recoveries received do not reduce the net claims of the risk-transferring insurance company below $50 \%$, they reduce the required solvability of the risk transferring insurance company and thus also increase the gross writing capacity legally attributable to a given amount of free capital.

- In the context of their service activity, reinsurance companies provide a range of assistance functions as may be required, inter alia in risk selection and rating. In this way the gross underwriting risk can already be reduced. Claims management is also frequently supported by the reinsurance companies ${ }^{94}$.

- In addition to the underwriting risk in its various forms, other types of risk can also be transferred by reinsurance. These include e.g. credit, price, interest alteration and currency risks of the investments backing the technical insurance policyholders' funds. This arises in particular in relation to the various forms of financial reinsurance which, in the case of young and strongly growing insurance companies, may also assist with development and financing support. Established insurance companies having good business relationships with their reinsurers based on mutual trust can sometimes resort to financial reinsurance to bridge over loss situations or liquidity crises which have arisen due to operating or financial business risks which have already materialised.

91 Reinsurance covers are determined to be continued (at least in Europe) subsequently to claims. Risk coverage by securitization presently offers no such protection. Cf. Womack, S.: A Capital Idea, in: The Post Magazine, Vol. 157, 14. November 1996, p. 31.

92 In addition, the collective risk equalisation in reinsurance portfolios is generally of superior quality because there is usually international diversification. Conversely, the rates of interest for consecutive issues of insurance-linked bonds to a varying purchasing public will be largely independent of each other; risk equalisation over time is thus not taken into consideration. The sole reference to the risks of only one insurance company also inhibits collective risk equalisation. Other things being equal, the price of risk transfer by securitization should therefore be comparatively higher compared with the security loadings in the rates of interest of the bonds. Cf. also Challis, $S$.: Stand-off on Wall Street, in: ReActions, (18) 1998, February, Special Supplement "Bermuda", p. 42 and Punter, A.: An Engagement is Announced, loc. cit., p. 9. At least initially, whilst investors are not very accustomed to the concept of securitization and the insurance risks thereby incurred, the security loadings required are likely to be higher than for conventional capital market securities with similar risk/yield structures. Cf. also Brooks, $K$. H.: loc. cit., p. 126 and Engeström, J.: loc. cit., p. 24.

${ }_{93}$ This ignores the diversification effect of the insurance-linked bonds with other types of investment in the portfolio and their value. In this connection see also Ballantine, $R$.: Bonding Experience, loc. cit., p. 93. Incidentally, it is to concede that the coverage obtained by the risk transfer via securitization just "does not have the ${ }^{\text {a }}$ character of a credit line', i.e. that a coverage once claimed will not have to be paid back over years as in fact it is usual for a common reinsurance contract. Further the price of the coverage does not have to be negotiated every year, but can be kept equal over years which is conducive to the cost estimating." Heri, E. W.; Frost, P.: loc. cit., p. 173.

${ }_{94}$ Cf. Womack, S.: loc. cit., p. 32. 
- A relatively high degree of economic efficiency can be attributed to an injection of capital into the reinsurance sector to provide risk cover. Whereas reinsurance companies only require a fraction of their own risk capital to cover individual risks because of the collective risk sharing principle, covering the same risks on the capital market by issuing insurance-linked bonds would require the amount of the issue to be at least as great as the capital at risk - if the investors are liable to the extent of their total capital invested. If their liability is limited because a minimum capital repayment is agreed, a corresponding multiple of the risk capital must be raised on the capital market for the insured risks to be covered ${ }^{95}$.

Notwithstanding the greater economic efficiency described above, particular problems for reinsurance arise from shortages of risk covering capacity. These are the problems with which this subject has been introduced at the beginning of this paper and which justifies its relevance:

- Actual shortages of the availability of reinsurance on grounds of capacity, or even reinsurance crises, compared with the existing total demand are in fact exceptional ${ }^{96}$. This is above all because of the international sharing and resharing of the large and largest insurance risks through chains of reinsurance or pools. Above all, however, catastrophe risks can give rise to problems where the claims potential requires a significant proportion of the world-wide reinsurance capacity or where, in extreme cases, even this is inadequate ${ }^{97}$.

- More frequently, an individual insurance company may face a shortage in relation to the particular reinsurance capacity available to him. This could arise e.g. from a badly selected $^{98}$ and/or underrated portfolio of a primary insurer's risks (proportional reinsurance) as well as a high level of reinsurance at the outset that should not be further increased in order to maintain the self-interest of the insurance company concerned in a risk-based underwriting and rating policy.

In relation to the risks of default, no generally applicable comments can be made. The fulfilment of reinsurance transactions depends largely on the credit-worthiness of the individual reinsurance companies. Particular security may lie in the deposit position.

In conclusion, it can be stated that reinsurance is well-nigh indispensable for the purpose of risk transfer of insurance companies. However, within certain limits,

95 Cf. Punter, A.: An Engagement is Announced, loc. cit., p. 9. In this argumentation, the deployment of the capital earmarked for covering the risk in the form of investments in the meantime is not taken into account. The resulting economic effects must be taken into account in any comprehensive assessment of the efficiency.

96 Those supply shortages which arise from lack of capacity can not easily be distinguished from those resulting from inadequate levels of reinsurance premiums obtainable.

${ }^{97} D^{\prime}$ Arcy, S. P.; France, V. G.: Catastrophe Insurance Futures, loc. cit., p. 210 et seq. emphasise the capacity limits of reinsurance for catastrophe risks. A plausible explanation is furnished by major natural catastrophe risks which affect very wide areas or areas with particularly high concentrations of value and therefore can not be adequately diversified on the reinsurance market. Cf. Hasekamp, U.: loc. cit., p. 366. The literature also refers to shortages of risk coverage capacity in certain regions which are particularly exposed to catastrophes. Cf. for example with reference to Florida and California Brooks, K. H.: loc. cit., p. 125.

${ }^{98}$ For example, this is particularly so in the case of regional insurers in areas particularly prone to natural catastrophes who have a large proportion of natural perils covers and are thus exposed to a high accumulation risk. Cf. again Brooks, $K$. H.: loc. cit., p. 125 et seq. 
securitization can nevertheless be of considerable assistance ${ }^{99}$. How wide these limits will be in the future will depend in particular on the development of the number of purchasers of insurance-linked bonds and the volume of capital which they can offer for risk covering purposes $^{100}$.

\section{Empirical examples of risk transfer based on the risk securitization concept}

In actual practice concrete schemes have already been proposed along the lines of transferring risk by means of risk securitization and there are also cases of relevant transactions, which in the meantime have actually been completed. Three examples are demonstrated below in which the essential features are explained and which are classified in the theoretical model.

(1) The Zurich 'Berseebank AG', a subsidiary of the 'American International Group Inc. (AIG)' gave consideration to the issue of insurance-linked bonds which would participate in the risk of natural catastrophes ${ }^{101}$. The target group of investors selected was the private investor. The issuer would be the 'Fully Funded Reinsurance Company Ltd' of Jersey, a company specially created for this purpose. This company would invest both the amounts contributed by the investors and the premiums paid by the insurance companies interested in a risk transfer in American Government securities. All natural perils giving rise to insured claims amounting in total to at least USD $6.3 \mathrm{bn}$. (for events in USA), USD 3 bn. (in Western Europe and Japan), USD 1.25 bn. (in the Caribbean) and USD 1 bn. (in Australia and New Zealand) would be regarded as natural catastrophes. The risk would thus be linked to the insured claims of the total market. On the occurrence of an event of apparently catastrophic proportions, generally recognised institutions would be engaged to determine the extent of the insured claims. In the USA this would be the 'Property Claims Services' and for claims elsewhere this would be 'Sigma', a subsidiary of the 'Swiss

${ }^{99}$ Cf. also ibid., p. 126.

100 Whether and if so, to what extent, an efficient market for securitization transactions which has once reached a larger volume would actually have the consequential effect of bringing pressure to bear on reinsurance premiums is not investigated further here (Ballantine, R.: Capitalising on Risk, loc. cit., p. 90 refers to this possibility). In this respect, however, it all depends on whether the investors provide complementary capital solely to increase the capacity for insurance coverage or whether substitutive capital is also being provided to replace, or to compete with, the coverage capacity of the primary and reinsurance companies. Cf. Kielholz, W.; Durrer, A.: loc. cit., p. 16 and also Zech, J., quoted in Womack, $S$.: loc. cit., p. 32, who accept the first premise or rather consider such a tendency to be more probable. An increase of risk-based capital for the purpose of insurance coverage and the expansion of the market supply of securitization is expected for the long term also by Heri, E. W.; Frost, P.: loc. cit., p. 169.

$101 \mathrm{Cf}$. in this and the following connection Aeberli, U.: AIG-Notes: $25 \%$ Rendite für Privatinvestoren (AIG-Notes: Yield of $25 \%$ for Private Investors), in: Schweizer Versicherung und Schweizerischer Versicherungs-kurier, (51) 1996, H. 9, p. 28; Figge, F.: loc. cit., p 10; Gonseth, M.: loc. cit., p. B11; Hase, M.: Alternativen des Risikotransfers via Securitization (Alternatives of Risk Transfer via Securitization), in: Versicherungswirtschaft, (53) 1998, p. 292; Jahn, T.: loc. cit., P. 151; König, M.: Der Anleger als "Rückversicherer" - Alternativer Risikotransfer mittels "KatastrophenAnleihen" nach deutschem Recht (The Investor as 'Reinsurer' - Alternative Risk Transfer by Means of 'Catastrophe Bonds' under German Law), loc. cit., p. 3 et seq.; Palan, D.: loc. cit., P. 184 et seq. and the following newspaper or periodical articles (all anon.): Mit jeder Naturkatastrophe sinkt die Rendite (The Yield sinks with every Natural Catastrophe), in: Handelsblatt, 23./24. August 1996, p. 17; Fortschreitende Verbriefung von Versicherungsrisiken (Progress in Securitization of Insurance Risks), loc. cit., p. 24; Wetten auf den Hurrikan (Betting on the Hurricane), in: Wirtschaftswoche, 29. August 1996, p. 84. 
Reinsurance Company'. The bonds would be constituted as USD nil coupon loans, i.e. there would be no defined rate of interest, instead provision would be included for repayment at a rate envisaged to be greater than the issue price of $80 \%$. The minimum subscription was USD 30,000 . The term of the loans was fixed at 24 months, but the period of the investors' liability was restricted to the first 15 months. If no natural catastrophe, as defined, occurred within this period the repayment was fixed at $100 \%$; which would give a possible yield of approx. $11.8 \%$ p.a. If just one natural catastrophe occurred, the repayment would be reduced to $85.5 \%$ and consequently the annual yield to $3.4 \%$. If two or more natural catastrophes occurred, the repayment would fall to $60 \%$, i.e. the investors would risk the whole of their yield and, in addition, $25 \%$ of their capital. The basis of the risk as set out was not a claim amount but the number of insured claim events exceeding certain minimum claim values, having reference, with varying amounts, to various continental, national, and regionally defined insurance markets (i.e. of several taken together) and consequently not to the experience of any single insurance company (acting as a primary carrier of the insurance risks) on which the risk transfer could be based. As a consequence, from the insurance companies' point of view, the efficiency of the risk transfer would be lessened to the extent that the composition of their own portfolio of insured natural perils differed from that of the governing market portfolio. In the end, the securitization concept described was not adopted in actual practice ${ }^{102,103}$.

(2) The second example refers to an actual transaction. At the beginning of 1997 the Swiss insurance company 'Winterthur' issued the first world-wide publicly placed 'catastrophe' bond, led by the 'Credit Suisse/First Boston'. The yield is linked to the number of hail and/or storm claims occurring in the motor vehicle comprehensive insurance branch ${ }^{104}$. More precisely, it is a three year subordinated convertible bond ${ }^{105}$.

102 In this context the formulations of Jahn and in the Handelsblatt article are misleading.

103 The considerations and activities of the berseebank exemplify that bringing together the insurance market and the capital market stems not only from insurance companies but is also undertaken by the banking sector, in particular by investment banks seeking new business fields. Cf. Punter, A.: An Engagement is Announced, loc. cit., p. 8 and Womack, S.: loc. cit., p. 31. In addition, some brokers have begun to develop alternative products for risk transfer involving capital market solutions. Cf. Punter, A.: Beyond the Fringe to Mainstream: Alternative Risk Financing Options, in: Lloyd¥s List, 19. November 1996 .

104 In this and the following connection cf. Credit Suisse/First Boston (publisher): Wandelanleihe Winterthur-Versicherungen mit WinCAT-Coupons "Hagel" (Winterthur Insurance Convertible Bond with WinCAT-Coupons "Hail"), arranged by K. Hess and M. Jaggi, Zurich, January 1997, p. 1 et seq. and Heri, E. W.; Frost, P.: loc. cit., p. 173 et seq. Cf. also Banham, R.: loc. cit., p. 63; Hase, M.: loc. cit., p. 292; König, M.: Der Anleger als "Rückversicherer" - Alternativer Risikotransfer mittels "Katastrophen-Anleihen" nach deutschem Recht (The Investor as 'Reinsurer' - Alternative Risk Transfer by Means of 'Catastrophe Bonds' under German Law), loc. cit., p. 4 et seq. and the following newspaper or periodical articles (all anon.): Bei Hagel keine Zinsen (No Interest if it Hails), in: Frankfurter Allgemeine Zeitung, 17. January 1997, p. 27; Hagelschäden als Geldanlage (Hail Damage as an Investment), in: Neue Zürcher Zeitung, 16. January 1997, p. 22; Der Kapitalanleger als Rückversicherer (The Capital Investor as Reinsurer), in: Zeitschrift für Versicherungswesen, (48) 1997, p. 96 et seq.; Winterthur begibt erstmals "Katastrophen"-Anleihen (Winterthur issues First Catastrophe Bonds), in: Handelsblatt, 16. January 1997, p. 25.

105 "At the end of the term, the holder has the right to convert his convertible bond into registered shares of "Winterthur" at the exercise price of CHF 940.00.... This implies a premium of approx. $20 \%$ on the basis of Winterthur's present stock exchange price." Credit Suisse/First Boston (publisher): loc. cit., p.5. At the end of July 1997 the stock exchange price of "Winterthur" shares was around CHF $1,500.00$. 
The total amount of the loan is CHF $300 \mathrm{~m}$., the coupon rate of interest is $2.25 \%$ and the issue price $100 \%$. The annual interest payment will be cancelled for any corresponding year in which more than 6,000 motor vehicles insured by 'Winterthur' under comprehensive policies are damaged by hail or storm;106 the bonds will however be repaid in full at the end of the term in any event so that investors run no risk of loss of capital $^{107,108}$. The investment risk is thus based on the number of insured claims in the portfolio of the insurance company transferring the risk. This reference to the experience of the company itself improves the effectiveness of the risk hedging from the company's point of view, although the use of the number of claims as opposed to the amount thereof somewhat reduces this.

(3) The third example is also an actual case. In December 1996, shortly before the Winterthur deal, the 'Hannover Reinsurance Company' announced a transaction'109 entered into with eight North-American institutional investors. In return for the provision of USD $100 \mathrm{~m}$. risk capital for the next five to seven years, the investors participate as to $50 \%$ in a defined reinsurance portfolio consisting of natural catastrophe and other risks (aviation and liability risks) in various countries and territorial regions (namely USA, Canada, Japan, Australia, Northern Europe). The other $50 \%$ is retained by the Hannover $\mathrm{Re}$ - which should create confidence in the investors. The basis of their liability is the combined operating ratio over the period of the transaction. If the ratio exceeds $100 \%$, which means a technical insurance loss the investors must carry half thereof; in the extreme case this could result in a total loss of their capital. If the combined operating ratio is under $100 \%$, the investors participate in one-half of the technical insurance profit.

106 The separate insurance periods are fixed as follows: For the first year's interest from 28.02.1997 to 31.10.1997, for the second year from 01.11.1997 to 31.10.1998 and for the third year from 01.11.1998 to 31.10.1999. The limiting number of claims of 6,000 will be adjusted on the first of April each year if the motor vehicle comprehensive insurance portfolio of "Winterthur" has changed by more than $10 \%$ from that of the previous year.

107 Three year convertible bonds, with similar conditions but without the catastrophe risk would normally carry an interest rate of approx. $1.49 \%$ at the time of issue on the Swiss market. The interest rate differential can be regarded as the equivalent for the assumption of the catastrophe risk by the investors. "If, during the three year period, only one major claim involving cancellation of the interest payment occurs, the total interest payments will still be better than under a normal bond. Only if the coupon were cancelled on two occasions as a result of higher claims would the normal bond be more advantageous." (Cf.) anon.: Der Kapitalanleger als Rückversicherer (The Capital Investor as Reinsurer), loc. cit., p. 97. During the last ten years there have in total been two hail storms (1992 and 1993) which would have led to cancellation of the interest payment.

108 The additional "reinsurance capacity" brought to the market by investors amounts to (only) CHF 6.75 million annually, i.e. $2.25 \%$ of dividend risk out of a total investment of CHF 300 million. With the transaction described above, the Winterthur does not (yet) seriously intend to 'reinsure' their insurance risks on the capital market, but to gain experience with this type of risk transfer in the structuring of the price and of the readiness of the (Swiss) capital market to subscribe thereto. Cf. anon.: Hagelschäden als Geldanlage (Hail Damage as an Investment), loc. cit., p. 22. Incidentally, the volume of the issue was reportedly heavily oversubscribed. Cf. anon.: Der Kapitalanleger als Rückversicherer (The Capital Investor as Reinsurer), loc. cit., p. 97.

${ }^{109}$ This was already the Hannover Re's second transaction in this business field, in which they were first active in 1994. Cf. in this and the following connection Banham, R.: loc. cit., p. 63; Fromme, H.: Hannover Re launches Capital Markets Venture, in: Insurance Day, 26. November 1996 and in the following newspaper articles (both anon.): Hannover Rück nutzt Kapitalmarkt für Rückversicherung (Hannover Re uses the Capital Market for Reinsurance), loc. cit., p. 23; Vorstofl im Bereich des alternativen Risikotransfers (Advances in the Field of Alternative Risk Transfer), loc. cit., p. 29. 
In the most favourable case, if the experience were to be completely claim-free, a return of $30 \%$ p.a. would be realised. It follows that the investors are assuming a significant speculative risk ${ }^{110}$ in participating in this transaction. By basing the loan risk on the combined operating ratio of its own reinsurance portfolio, the efficiency of the risk hedging is of a high degree from the point of view of the Hannover $\mathrm{Re}$ as the risk transferring insurance company. After taking into account the investors' proportion of the reinsurance portfolio, potential losses in excess of USD $100 \mathrm{~m}$. fall into the self-retention of the Hannover Re as the limit of USD $100 \mathrm{~m}$. represents so to speak the investors' layer of exposure 111 .

The Hannover Reinsurance Company plans to enter into further risk transfers with institutional investors in future on the securitization basis. These may extend beyond the classes of risks so far dealt with e.g. including crop damage and political risks ${ }^{112}$. profit.

${ }^{110}$ In risk theory, the term 'speculative risk' embraces both the risk of loss and the chance of

111 It should be particularly noted that, by the inclusion of the (business's) expense ratio in the parameter for the investors' entitlements, not only the cost of claims risk of the particular reinsurance portfolio but also the risk of excess expenses, not related to claims, is transferred to the capital market.

112 For information regarding further empirical examples of current securitization transactions and of those still at the planning stage as well as those which have been discarded or have failed, see Adams, C.; Authers, J.: Fresh Sales of Catastrophe Securities, in: Financial Times, 10. June 1998; anon.: St Paul Re Securitisation Transaction, in: ReActions (17) 1997, February, p. 8; Ballantine, R.: Bonding Experience, loc. cit., p. 93; ibid.: Capitalising on Risk, loc. cit., p. 90; Banham, R.: loc. cit., p. 63 et seq.; Beatty, A.: Securitisation Starts to Make its Mark, in: Reinsurance, May 1998, p. 1; Booth, G.: Go Ahead for Risk Bonds, in: ReActions, (17) 1997, January, p. 8; Challis, S.; Booth, G.: loc. cit., p. 20 et seq.; Clow, R.: loc. cit., p. 141; Dowding, T.: loc. cit., p. 6; Mansion, Y.; Cossu, P.: loc. cit., p. 82; Müller, E.: loc. cit., p. 600; Punter, A.: Beyond the Fringe to Mainstream: Alternative Risk Financing Options, loc. cit.; ibid.: Something out of the Ordinary, loc. cit., p. 18; Quick, C.: loc. cit.; Smith, R. E.; Cancelo, E. A.; Di Dio, A. M.: loc. cit., p. 34; Womack, S.: loc. cit., p. 31 and 32 and Kielholz, W.; Durrer, A.: loc. cit., p. 8 et seq. Kielholz and Durrer describe in detail the so-called 'Earthquake Risk Bond', the first publicly discussed and well documented insurance-linked bond, with which the 'California Earthquake Authority' wished to transfer a greater part of the earthquake risk onto the capital market (see also in this connection anon.: Innovationspreis für einen Versicherungsplan (Prize for Innovation for an Insurance Plan), in: Handelsblatt, 28. October 1996, p. 21 and Punter, A.: An Engagement is Announced, loc. cit., p. 8 et seq.). However, in the result, the issue did not come to fruition (cf. anon.: Rückversicherung besser als Erdbeben-Anleihe (Reinsurance better than Earthquake Bond), in: Handelsblatt, 25. November 1996, p. 17 and Smith, R. E.; Cancelo, E. A.; Di Dio, A. M.: loc. cit., p. 35). Unfortunately, most of the other reports to be found in the literature concerning actual or potential securitization transactions are so vague as to give little more than a fleeting impression of their construction. One reason is undoubtedly the policy of safeguarding information followed by the institutions concerned. Cf. again Banham, R.: loc. cit., p. 64.

In the recent past, primarily in the USA, existing specialist company divisions or even new specialist companies have been set up in order to research areas of 'alternative risk transfer' and 'risk securitization' in particular and to develop business, advise and service clients and/or themselves to participate in the market. In this connection see, for example, anon.: Hannover Rück nutzt Kapitalmarkt für Rückversicherung (Hannover Re uses the Capital Market for Reinsurance), loc. cit., p. 23; Beatty, A.: loc. cit., p. 1; Challis, S.; Booth, G.: loc. cit., p. 20; Hase, M.: loc. cit., p. 292; Fox, D.: Normandy Re to Develop Investment Instruments, in: The Royal Gazette, 22. June 1995 and Fromme, $H$.: loc. cit. A highly relevant example of development activity is the design and setting up of loss indices which on the one hand make the standardisation of risk transfer by securitization possible but on the other adequately safeguard the particular risk transfer requirements of individual insurance companies. Cf. e.g. Womack, S.: loc. cit., p. 32. 


\section{REFERENCES}

ADAMS, C.; AUTHERS, J.: Fresh Sales of Catastrophe Securities, in: Financial Times, 10. June 1998.

AEBERLI, U.: AIG-Notes: 25\% Rendite für Privatinvestoren (AIG-Notes: Yield of $25 \%$ for Private Investors), in: Schweizer Versicherung und Schweizerischer Versicherungs-kurier, (51) 1996, H. 9 , p. 28.

ALBRECHT, P.; KÖNIG, A.; SCHRADIN, H. R.: Katastrophenversicherungs-Terminkontrakte: Eine Finanzinnovation und ihre Bedeutung für die (Rück-)Versicherung von Katastrophenrisiken (Catastrophe Insurance Futures: A Financial Innovation and its Significance for the (Re)Insurance of Catastrophe Risks), in: Zeitschrift für die gesamte Versicherungswissenschaft, (83) 1994, p. 633-682.

anon.: Bei Hagel keine Zinsen (No Interest if it Hails), in: Frankfurter Allgemeine Zeitung, 17. January 1997, p. 27.

anon.: Hagelschäden als Geldanlage (Hail Damage as an Investment), in: Neue Zürcher Zeitung, 16. January 1997, p. 22.

anon.: Hannover Rück nutzt Kapitalmarkt für Rückversicherung (Hannover Re uses the Capital Market for Reinsurance), in: Frankfurter Allgemeine Zeitung, 03. December 1996, p. 23.

anon.: Innovationspreis für einen Versicherungsplan (Prize for Innovation for an Insurance Plan), in: Handelsblatt, 28. October 1996.

anon.: Der Kapitalanleger als Rückversicherer (The Capital Investor as Reinsurer), in: Zeitschrift für Versicherungswesen, (48) 1997, p. 96 et seq.

anon.: Münchener Rück zur weltweiten Verstädterung (Munich Re on World-wide Urbanisation), in: Die Versicherungspraxis, (87) 1997, p. 115.

anon.: Mit jeder Naturkatastrophe sinkt die Rendite (The Yield sinks with every Natural Catastrophe), in: Handelsblatt, 23./24. August 1996, p. 17.

anon.: Naturkatastrophen mit Anlegergeldern versichern (Insuring Natural Catastrophes with Investors' Funds), in: Handelsblatt, 23. July 1996, p.13.

anon. (H.C.): Extreme Risiken durch weltweite Verstädterung (Extreme Risks resulting from Worldwide Urbanisation), in: Versicherungswirtschaft, (52) 1997, p. 851-852.

anon: Risikotransfer über Finanzmärkte (Risk Transfer via Capital Markets), in: Die Versicherungspraxis, (86) 1996, p. 166-168.

anon.: Rückversicherung besser als Erdbeben-Anleihe (Reinsurance better than Earthquake Bond), in: Handelsblatt, 25. November 1996, p. 17.

anon.: Spreading Catastrophe Risk through Reinsurance and Capital Markets Reviewed at Joint Industry Forum, in: Insurance Research Letters Americas, 1997, No. 3, p. 4-6.

anon.: St Paul Re Securitisation Transaction, in: ReActions (17) 1997, February, p. 8.

anon.: Fortschreitende Verbriefung von Versicherungsrisiken (Progress in Securitization of Insurance Risks), in: Neue Zürcher Zeitschrift, 23. August 1996, p. 24.

anon.: Vorstofl im Bereich des alternativen Risikotransfers (Advances in the Field of Alternative Risk Transfer), in: Handelsblatt, 04./05. October 1996, p. 29.

anon.: Wetten auf den Hurrikan (Betting on the Hurricane), in: Wirtschaftswoche, 29. August 1996, p. 84 .

anon.: Winterthur begibt erstmals "Katastrophen"-Anleihen (Winterthur issues First Catastrophe Bonds), in: Handelsblatt, 16. January 1997, p. 25. 
BALLANTINE, R.: Bonding Experience, in: ReActions, (16) 1996, September, p. 91-93.

BALLANTINE, R.: Capitalising on Risk, in: ReActions, (16) 1996, September, p. 89-90.

BANHAM, R.: Breaking Barriers, in: ReActions, (17) 1997, March, p. 63.

BEATTY, A.: Securitisation Starts to Make its Mark, in: Reinsurance, May 1998, p. 1.

BOOTH, G.: Go Ahead for Risk Bonds, in: ReActions, (17) 1997, January, p. 8.

BROOKS, K. H.: New Ways to Cut US Catastrophe Exposures, in: ReActions, (16) 1996, September, p. $125-126$.

CHALLIS, S.: Stand-off on Wall Street, in: ReActions, (18) 1998, February, Special Supplement "Bermuda", p. 4l-42.

CHALliS, S.; BOOTH, G.: Cat Bond Bounce?, in: ReActions, (18) 1998, April, p. 20-21.

CLOW, R.: Coping with Catastrophe, in: Institutional Investor, December 1996, p. 137-142.

COX, S. H.; SCHWEBACH, R. G.: Insurance Futures and Hedging Insurance Price Risk, in: Journal of Risk and Insurance, (59) 1992, p. 628-644.

Credit Suisse/First Boston (publisher): Wandelanleihe Winterthur-Versicherungen mit Win-CATCoupons "Hagel" (Winterthur Insurance Convertible Bond with WinCAT-Coupons "Hail"), arranged by K. Hess and M. Jaggi, Zürich, January 1997.

D'ARCY, S. P.; FRANCE, V. G.: Catastrophe Futures: A Better Hedge for Insurers, in: Journal of Risk and Insurance, (59) 1992, p. 575-601.

D'ARCY, S. P.; FRANCE, V. G.: Catastrophe Insurance Futures, in: CPCU Journal, (46) 1993, p. 202-213.

DOWDING, T.: Safe as Houses?, in: The Post Magazine, Vol 158, 6. March 1997, p. 6.

DURRER, A.: Alternativer Risikotransfer über Finanzmärkte (Alternative Risk Transfer via Capital Markets), in: Versicherungswirtschaft, (51) 1996, p. 1198-2000.

ENGESTRÖM, J.: Capital Idea, Interview mit G. Booth, in: ReActions, (16) 1996, August, p.24.

FIGGE, F.: Spekulieren mit der Katastrophe (Speculating with Catastrophe), in: Blick durch die Wirtschaft, 23. October 1996, p. 10.

FOX, D.: Normandy Re to Develop Investment Instruments, in: The Royal Gazette, 22. June 1995.

FROMME, H.: Hannover Re launches Capital Markets Venture, in: Insurance Day, 26. November 1996.

GEMAN, H.: Insurance Risk Securitization and Cat Insurance Derivatives, unpublished lecture manuscript, Paris, July 1996 (Publication in the periodical "Financial Derivatives and Risk Management" was due in September 1996).

GOLLIER, C.: About the Insurability of Catastrophic Risks, in: The Geneva Papers on Risk and Insurance, (22) 1997, p. 177-186.

GONSETH, M.: Assekuranz transferiert Risiken immer stärker auf die Finanzmärkte (Insurance Increasingly Transfers Risks to the Capital Markets), in: Handelsblatt, 24. September 1996, p. B 11.

GROTH, C. H.: A Rising Tide? The Converging Capital and Insurance Markets, in: Risk Management, (44) 1997, No. 2, p. 20-26.

HASE, M.: Alternativen des Risikotransfers via Securitization (Alternatives of Risk Transfer via Securitization), in: Versicherungswirtschaft, (53) 1998, p. 291-293. 
HASEKAMP, U.: Insurance Futures - eine Finanzinnovation als Hedging-Instrument gegen Katastrophenrisiken? (Insurance Futures - a Financial Innovation as a Hedging Instrument against Catastrophe Risks?), in: Versicherungswirtschaft, (49) 1994, p. 361-367.

HERI, E. W.; FROST, P.: Versicherungsrisiken an den Finanzmärkten. Die erste kotierte ${ }^{a}$ CAT'Anleihe (Insurance Risks at Capital Markets. The first official listed ${ }^{a}$ CAT'-Bond), in: Asset Management: Finanzdienstleistungen von und für Versiche-rungen, published by E. Henn, Stuttgart 1998, p. 167-177.

HIMICK, M.: CBOT PCS Cat Options, in: Reinsurance, September 1996, p. 19-21.

JAHN, T.: Wetten auf das Wetter (Betting on the Weather), in: Capital, November 1996, p. 151.

KIELHOLZ, W.; DURRER, A.: Insurance Derivatives and Securitization: New Hedging Perspectives for the US Cat Insurance Market, in: the Geneva Papers on Risk and Insurance, (22) 1997, No. 82 , p. 3-16.

KÖNIG, M.: Der Anleger als "Rückversicherer” - Alternativer Risikotransfer mittels "KatastrophenAnleihen" nach deutschem Recht (The Investor as 'Reinsurer' - Alternative Risk Transfer by Means of 'Catastrophe Bonds' under German Law), Working paper 4/97 of the Institut für Handels- und Wirtschaftsrecht (Institute for commercial and business law), University of Osnabrück.

LEVIN, A. M.; ELKIND, C. K.: Solutions in Search of a Problem, in: ReActions, (17) 1997, June, p. $44-45$.

MAGENHEIM-HÖRMANN, T.: Die Angst der Assekuranz vor der Metropole (Insurers' Worries in Connection with the Metropolis), in: Frankfurter Rundschau, 16. May 1997, p. 11.

MANSION, Y.; COSSU, P.: Assurance et finance - Vers un pont $\ddagger$ double voie?, in: Risques, No. 28 , 1996, p. 77-88.

MEYER, B.: Cover need not be Catastrophic, in: Reinsurance, July 1996, p. 37-38.

MÜLLER, E.: Securitization ñ Quo Vadis?, in: Zeitschrift für Versicherungswesen, (48) 1997, p. $597-$ 604.

PUNTER, A.: An Engagement is Announced, in: Reinsurance, April 1996, p. 8-9.

PUNTER, A.: Beyond the Fringe to Mainstream: Alternative Risk Financing Options, in: Lloyd¥s List, 19. November 1996.

PUNTER, A.: Something out of the Ordinary, in: Reinsurance, December 1997, p. 17-18.

QUICK, C.: Securitization 'First' on Non-Disaster Risks, in: Insurance Day, 08. April 1997.

REHMANN, J.: Vierzig Jahre Nuklearversicherung: Ist das Poolsystem noch zeitgemäfl? (Forty Years of Nuclear Insurance. Is the Pool System still Appropriate to the Times?), in: Neue Wege des Versicherungsmanagements (New ways in insurance management), Festschrift for the 60th. birthday of Günter Schmidt, ed. by J.-M. Graf von der Schulenburg, Karlsruhe 1997, p. 305-323.

Swiss Re (publisher): Natural Catastrophes and Major Losses 1996: High Man-made Losses, Absence of extremely costly Natural Catastrophes, in: sigma, 1997, No. 3, p. 1-38.

SHIMPI, P.: The Context for Trading Insurance Risks, in: The Geneva Papers on Risk and Insurance, (22) 1997, p. 17-25.

SMITH, R. E.; CANCELO, E. A.; DI DIO, A. M.: Reinventing Reinsurance Using the Capital Markets, in: The Geneva Papers on Risk and Insurance, (22) 1997, p. 26-37.

THOMAS, B.: Insurance Meets Wall Street, in: Risk Management, (44) 1997, No. 5, p. 15.

VUKELIC, M.: Access to a Wealth of Capital Ideas, in: Reinsurance, September 1996, p. 17-19. 
WEBER, M.: Cat Option Critique, in: Reinsurance, September 1996, p. 21-22.

WOMACK, S.: A Capital Idea, in: The Post Magazine, Vol. 157, 14. November 1996, p. 31-32.

Gesetz über die Beaufsichtigung der privaten Versicherungsunternehmen (Versicherungsaufsichtsgesetz, VAG) (German Insurance Supervisory Law).

Rundschreiben R 3/88 des Bundesaufsichtsamts für das Versicherungswesen (Circular R 3/88 of the German Federal Insurance Supervisory Office), in: VerBAV, (37) 1988, p. 195-206.

Verordnung über die Kapitalausstattung von Versicherungsunternehmen (KapitalausstattungsVO) (German Capital Requirement regulation). 